
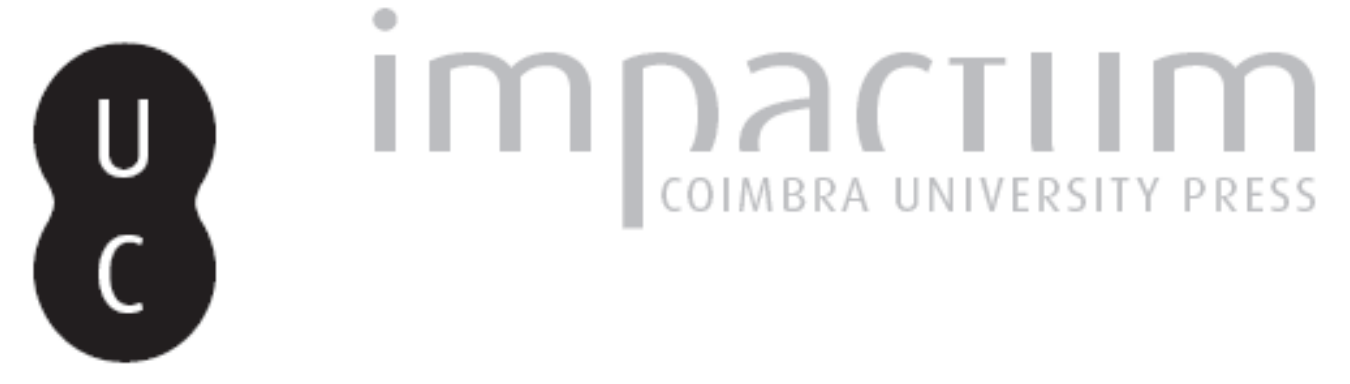

\title{
Os Cistercienses e a água
}
Autor(es): Jorge, Virgolino Ferreira
Publicado por: Faculdade de Letras da Universidade de Coimbra, Instituto de História Económica e Social

URL

persistente:

URI:http://hdl.handle.net/10316.2/29892

DOI:

DOI:http://dx.doi.org/14.14195/0870-4147_43_2

Accessed : $\quad$ 26-Apr-2023 10:48:16

A navegação consulta e descarregamento dos títulos inseridos nas Bibliotecas Digitais UC Digitalis, UC Pombalina e UC Impactum, pressupõem a aceitação plena e sem reservas dos Termos e Condições de Uso destas Bibliotecas Digitais, disponíveis em https://digitalis.uc.pt/pt-pt/termos.

Conforme exposto nos referidos Termos e Condições de Uso, o descarregamento de títulos de acesso restrito requer uma licença válida de autorização devendo o utilizador aceder ao(s) documento(s) a partir de um endereço de IP da instituição detentora da supramencionada licença.

Ao utilizador é apenas permitido o descarregamento para uso pessoal, pelo que o emprego do(s) título(s) descarregado(s) para outro fim, designadamente comercial, carece de autorização do respetivo autor ou editor da obra.

Na medida em que todas as obras da UC Digitalis se encontram protegidas pelo Código do Direito de Autor e Direitos Conexos e demais legislação aplicável, toda a cópia, parcial ou total, deste documento, nos casos em que é legalmente admitida, deverá conter ou fazer-se acompanhar por este aviso.

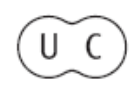





\title{
Os Cistercienses e a Água
}

\author{
Virgolino Ferreira Jorge \\ Professor aposentado da Universidade de Évora \\ vfjorge@gmail.com
}

\section{Resumo:}

Na literatura tradicional sobre os Cistercienses, os aspectos relacionados com a sua higrofilia mantêm-se pouco conhecidos. Com este trabalho, pretende-se contrariar esta "iliteracia" hidráulica e mostrar que os "monges brancos" também alcançaram uma competência indiscutível na área da exploração e dos usos económicos da água. Tal notoriedade foi decisiva para o alcance, alargado e frutuoso, das suas comunidades medievais. Os mosteiros, para funcionarem em condições de higiene e sanidade adequadas, careciam de um hidrossistema sólido e tecnicamente eficiente, na forma e no traçado, desde a captação de águas, seu transporte e distribuição pelo interior dos cenóbios, até à evacuação dos resíduos domésticos e pluviais. Tal empreendimento obrigou à realização de elaborados e árduos trabalhos, alguns preliminares ao levantamento dos edifícios comunitários. Na amplitude das suas manifestações concretas, a história dos mosteiros cistercienses medievais é também uma história da relação estreita e longa do homem com a água. Dois elementos de estudo tão extensos como significativos, na sua acepção e importância religiosa, cultural, socioeconómica e ambiental. A totalidade dessas acções e razões objectivas autorizam, quiçá sem exagero de afirmação, o argumento favorável a um intuído "modelo" cisterciense de arquitectura hidráulica, o qual constitui um campo aberto de estudo e discussão privilegiados.

\section{Palavras chave:}

Cistercienses; Hidráulica Monástica; Monaquismo e Tecnologia.

\section{Abstract:}

In traditional writings about the Cistercians, the aspects relating to their "hydrophilia" are still little known. With this work, we intend to counteract this " hydraulic illiteracy" and show that the "white monks" also reached an indisputable competence in the area of survey and economic uses of water. Such competence was decisive for the scope, extended and fruitful, of their medieval communities. In order to work on proper health and hygiene conditions, the monasteries needed a solid and technically efficient hydrosystem, both in its shape and network, going from the water intake, transport and distribution within the cenobia, to the evacuation of household waste and rain water. This venture led to elaborated and strenuous works, some of them prior to the raising of community buildings. In the wide range of its tangible results, the history of medieval Cistercian monasteries is also a history of a long and close relationship between man and water. These are two topics of study as vast as meaningful in its religious, cultural and socio-economic context and relevance. The contents of these actions and objective reasons authorize, perhaps without exaggeration, the argument in favour of an intuitive "model" of Cistercian hydraulic architecture, which constitutes an open field of privileged study and discussion.

Keywords:

Cistercians; Monastic hydraulics; Monasticism and technology. 


\section{Nota Introdutória}

Apesar de a literatura tradicional sobre os Cistercienses ser muito abundante e diversificada, os aspectos relacionados com a sua higrofilia ou quase obsessão pela água mantêm-se pouco conhecidos ou de tratamento restrito. Daí, não terem ainda constituído um tema de estudo aprofundado ${ }^{1}$.

Em face a outros domínios de avaliação e dimensão mais visíveis daquela Ordem, como exemplificam a arquitectura e as artes, essa lacuna poderá parecer pouco relevante para merecer preferência ou atenção de pesquisa e debate aberto qualificados. Com este trabalho sumário, pretende-se contrariar esta injusta "iliteracia" hidráulica e mostrar que os "monges brancos" também alcançaram uma competência indiscutível e complementar na área da exploração e dos usos económicos da água. Tal notoriedade foi decisiva para o alcance, alargado e frutuoso, das suas comunidades medievais, como tentaremos esclarecer abaixo em termos simples e breves. Os mosteiros, para funcionarem em condições de higiene e sanidade adequadas, careciam de um hidrossistema sólido e tecnicamente eficiente, na forma e no traçado, desde a captação de águas potável e comum, seu transporte por gravidade, armazenamento e distribuição pelo interior dos cenóbios, até à evacuação normal dos resíduos domésticos e pluviais. Trata-se de um património vasto, difuso e parcialmente subterrâneo, de acesso escondido ou difícil, que se estende pela vizinhança das suas antigas cercas; hoje, em geral, são todas de propriedade privada, devido ao banimento oitocentista das ordens regulares ${ }^{2}$. Com a desactivação e abandono destas vetustas obras de arte, deixaram de ser executadas as acções periódicas para a sua conservação e manutenção. Sujeitas ao tempo, as consequentes roturas e entupimentos provocaram a decrepidez acelerada dos materiais e a deformação das estruturas, algumas delas em lastimável estado de atomização

\footnotetext{
1 Entretanto, o conhecimento arqueológico de alguns sistemas hidráulicos monástico-conventuais medievos começou a suscitar o interesse e a admiração de arqueólogos e de historiadores das técnicas pelo debate crescente do tema. Nesse sentido, os colóquios de Royaumont (1992), da Arrábida (1993) e de Ratisbona (1997) constituíram uma iniciativa essencial e propulsora para a reflexão aberta e o desenvolvimento histórico do património hidráulico das comunidades regulares, numa perspectiva multidisciplinar e de intercâmbio internacional, com manifesta dominância pelos sítios cistercienses. Vejam-se as actas destes congressos, respectivamente, em Léon Pressouyre e Paul Benoit (eds.), L'hydraulique monastique. Milieux, réseaux, usages, Grâne, Créaphis, 1996; José Manuel Mascarenhas, Maria Helena Abecasis e Virgolino Ferreira Jorge (eds.), Hidráulica Monástica Medieval e Moderna, Lisboa, Fundação Oriente, 1996; e Helmut-Eberhard Paulus, Hermann Reidel e Paul W. Winkler (eds.), Wasser. Lebensquelle und Bedeutungsträger, Ratisbona, Schnell \& Steiner, 1999.
}

2 Cf. alvará régio de 30 de Maio de 1834. 
ou ruína iminente. Não é de admirar, portanto, que, até há pouco tempo, este assunto fosse negligenciado e estivesse afastado dos interesses correntes da investigação nacional.

De modo lento, mas progressivo, assistimos ao despertar para as questões de hidráulica das antigas comunidades religiosas no País, sobretudo entre os estudiosos mais sensibilizados para a protecção da nossa herança histórica edificada. Esse conhecimento retrospectivo e aditivo, de especialidade recente, facilita e amplia a leitura e a compreensão funcionais e integradas do programa hídrico na organização do desenho arquitectónico e espacial dos mosteiros. Logo, é de todo o merecimento e vantagem garantir a sua posteridade e o valor utilitário e cultural que reflectem.

Os testemunhos "aquosos" apresentados, nos seus traços genéricos mais relevantes e numa abordagem necessariamente exígua do nosso passado cisterciense medieval, certificam um repertório diversificado de saberes práticos e de técnicas construtivas dos incansáveis monges brancos, mas caídos em desuso ou a funcionar modificados por novos equipamentos hidromecânicos. Esta variedade de experiências e de aptidões legadas, acerca da conquista e do uso intensivo da água, legitima uma porção substancial de memória identitária bastante ignorada e ameaçada, que ultrapassa a história da tecnologia e urge recuperar e restabelecer na pluralidade da nossa cultura. É uma obrigação ética comum evitar o colapso destes importantes projectos hidráulicos centenários - trabalhos anónimos e visualmente despercebidos, mas não esquecidos -, atribuídos à ousadia e à firmeza de espírito dos Cistercienses. Amiúde, eles são vitimados por facilitações mesquinhas e actos abusivos de interesse privado económico-especulativo, que apagam ou ocultam o seu valor e significado histórico-patrimonial. Por conseguinte, é improrrogável a nossa mobilização cautelar, assente no respeito e na responsabilidade desses bens herdados dos antepassados, a fim de assegurarmos a sua salvaguarda, ciente e consciente, num propósito correlacionado de usufruto e defesa estáveis do nosso devir civilizacional.

\section{Implantação das Abadias}

O estudo da hidráulica dos mosteiros cistercienses medievos pressupõe a compreensão e o conhecimento abonados dos factores físicos e ambientais que influenciaram a escolha atractiva dos seus lugares de fundação, isto é, do genius loci. As implantações requeriam um quadro natural com especificidades de configuração restritivas e singulares que as distingue de outros contextos topográficos de vida religiosa regular. Antes de qualquer assentamento, 
era necessário estudar o sítio a "urbanizar" e as condições antecipatórias para a sua organização programática disciplinada e racional, a fim de elas garantirem a prosperidade e a conveniência do futuro habitat. O processo requeria uma vistoria prévia dos locais anunciados (doados ou solicitados), especialmente quanto ao seu isolamento, abundância de água, pedra e madeira e à fertilidade dos solos a arrotear, efectuada por uma comissão de abades experientes e idóneos, e a sua homologação pelo Capítulo Geral da Ordem. Contudo, por vezes, após algum tempo de permanência dos monges numa determinada área, a insalubridade do sítio ou a inaptidão dos terrenos húmidos obrigou ao abandono e trasladação para um lugar mais favorável, onde hoje se encontram sedeados. Deste modo, garantiu-se a desejada estabilidade do ideal beneditino - oração e trabalho (ora et labora) - consubstanciado e consentido na aventura cisterciense, em fraterna simbiose e com o adequado equilíbrio entre o crer, o ser e o viver em comum ${ }^{3}$.

A aldeia cisterciense medieval formava um complexo de extraordinária unidade orgânica, retirado de aglomerados habitacionais consolidados e de grandes eixos viários. Uma localização topográfica adequada ao seu incremento futuro parece firmar-se, deveras, nas possibilidades efectivas da "revolução" agrícola dos campos, como garantia de existência material e autónoma dos monges. Com efeito - tanto ontem como hoje -, a presença e a disponibilidade de água potável e abundante são factores imprescindíveis para a vitalização e o desenvolvimento sustentado de uma comunidade humana fixa; donde, a sua importância decisiva nas particularidades da escolha do sítio a ocupar por uma "abadia branca" e na construção do seu cenário de enquadramento, estreitamente ergonomizado com a paisagem local ${ }^{4}$.

A sede e a dependência da água implicaram que os cenóbios fundeiros estivessem debaixo da ameaça constante de inundações provocadas pelas torrentes do rio ou ribeiro próximos. Por isso, a generalidade dos complexos

\footnotetext{
3 Por motivos que radicam na sustentabilidade do lugar cisterciense (nomeadamente, devido a causas hidrológicas), estas transferências foram mais habituais e necessárias em mosteiros resultantes da afiliação de antigas comunidades eremíticas à Ordem (abadias adoptadas) do que em fundações ex novo (por exemplo, em Tarouca, Salzedas ou Águias).

4 O valor e o significado insuperáveis da água para a subsistência de uma comunidade cisterciense apoiam a opinião de alguns autores de que o motivo primário para a escolha dos locais de fundação, em vales verdejantes e na proximidade de rios, foi menos a vontade de vida solitária e mais a preferência racional por espaços com um forte potencial hídrico. Cf. Winfried Schich, "Die Wirtschaftstätigkeit der Zisterzienser im Mittelalter: Handel und Gewerbe", em K. Elm, P. Joerissen e H. J. Roth (eds.), Die Zisterzienser. Ordensleben zwischen Ideal und Wirklichkeit, Colónia, Rheinland-Verlag, 1981, p. 218, e vários estudos afins reunidos em Léon Pressouyre (ed.), L'Espace Cistercien, Paris, Comité des travaux historiques et scientifiques, 1994.
} 
abaciais à borda-d'água respeita o leito das cheias ou ergue-se sobre um aterrado ou plataforma artificial que os protege desses alagamentos devastadores, além de dificultar as ocorrências de humidade ascensional nas construções ${ }^{5}$. As medidas cautelares de terrapleno, modelação, nivelamento e compactação da área crítica aluvial obrigaram ao projecto e à execução simultânea de várias infra-estruturas hidrotécnicas e sanitárias específicas e complexas, adaptadas previamente à configuração do sítio e à implantação sobreposta e posterior dos diversos edifícios regulares. Entre outras obras, nomeie-se a construção emparedada de canalizações de atravessamento, mesmo que a provisão de água potável ao cenóbio, por intermédio de um conduto, seja de época um pouco mais recente.

O estabelecimento dos mosteiros, sobretudo daqueles localizados em zonas algo mais afastadas de nascentes e de cursos de água ou em áreas de paul, obrigou também à realização de elaborados e árduos trabalhos, alguns igualmente preliminares ao levantamento dos edifícios comunitários. São de aludir o desvio de linhas de água, a regularização de caudais, o desassoreamento de rios, a construção de açudes, a abertura de levadas ou a execução de sistemas de enxugo e drenagem e de abastecimento e evacuação de águas, além de outras diligências. Estas construções e obras de controlo e ordenamento hidráulico e do solo, maioritariamente concebidas e realizadas ex nihilo, com o espírito e a força empreendedora e paciente dos monges, desenharam e humanizaram a paisagem circundante, conferindo-lhe uma nova beleza e identidade ${ }^{6}$. Elas decorreram das circunstâncias de fundação e da exigência funcional do modo de vida monástica institucionalizada em autarcia, explicitamente solicitadas pela observância da Regra de São Bento de Núrsia (c. 480 - c. 547).

A Regra Beneditina determina também que as comunidades vivam em residência fixa (stabilitas loci), devendo estar apetrechadas com os meios próprios que garantam essa auto-suficiência e evitem que os monges sejam forçados a sair do mosteiro. De acordo com as palavras dos versículos 6-7 do capítulo LXVI da Regra, tal ausência "não convém nada à sua alma”, pelo que, "se for possível, o mosteiro será construído de maneira que se encontrem no seu

5 Um informante idoso, que trabalhou nas obras de restauro do Mosteiro de Alcobaça, na década de 1930, esclareceu-me e assegurou-me, entre outras coisas, a existência de um poço de ressumação, localizado no braço sul do transepto da igreja, descoberto com os trabalhos de rebaixamento e consolidação do piso.

6 Sobre trabalhos e actividades de exploração e transformação da paisagem rural empreendidos em Alcobaça, ver José Manuel Mascarenhas, Pedro Gomes Barbosa e Virgolino Ferreira Jorge, "Les Cisterciens et l'aménagement de l'espace. Le cas d'Alcobaça", em L'Espace Cistercien, cit., p. 153-164. 
interior todas as coisas necessárias, isto é, a água, o moinho e o pomar, e que aí se possam exercer os diversos ofícios" "É nesta antiga perícope que radicam os esforços de sustentabilidade económica e material dos laboriosos Cistercienses medievais, libertando-os da dependência e do contacto físico com o mundo dos homens, cujo refúgio e despojamento estão na génese da sua espiritualidade (monge, do vocábulo grego monakhós 'solitário'). Para a concretização da empresa monástica, nem a Regra nem os Estatutos da Ordem prescrevem ou fixam quaisquer instruções de trabalho ou procedimentos técnicos gerais ou específicos acerca da arquitectura, do abastecimento e da evacuação da água ou da irrigação agrícola. Esta "falta" de um directório formal pode causar estranheza, porquanto essas obras seriam impensáveis sem os conhecimentos e as competências aplicadas do Quadrivium (Aritmética, Geometria, Música e Astronomia). O "segredo" ou a obscuridade normativa não surpreendem nem são excepcionais. Devem-se aos métodos coevos de transmissão oral e restrita cifrada dos saberes práticos adquiridos directamente nos estaleiros das construções, para além de poderem flexibilizar ou suscitar ajustamentos aos costumes e às possibilidades autóctones próprios dos diferentes sítios de fundação.

No planeamento prévio e minucioso de um conjunto monástico era indispensável e de alcance técnico considerar a incorporação dos edifícios com as infra-estruturas hidráulicas intrínsecas, como mostra a planta-tipo de uma abadia de Cister, do período medieval (Fig. 1). Este padrão, ao qual se vinculam de modo genérico os mosteiros da Ordem, apresenta o complexo claustral implantado do lado sul da igreja, seguramente para obter uma melhor insolação dos compartimentos residenciais, aproveitar o máximo de luminosidade natural e estar protegido dos ventos. O ganho solar permite combater o desconforto da grande inércia térmica dos materiais de construção, sentido durante os rigores do Inverno. A proporção de abadias com essa disposição meridional prova esta preferência da Ordem, sempre que as condições hidrogeológicas do sítio o permitem. Em casos contrários, os lugares regulares estão a norte ou a sul do edifício eclesial, consoante a pendente do terreno e a direcção favorável ao escoamento da linha de água, o que facilita o desempenho eficiente da sua rede hidráulica. Devido a esta exposição física e ao preceito medieval de orientação do eixo maior da igreja para o lado nascente, o templo ocupa sempre a zona de maior cota topográfica e pode ficar a montante do

7 Citado e traduzido da Règle de Saint Benoît, Rochefort, Abadia de São Remy, 1980, p. 181. 


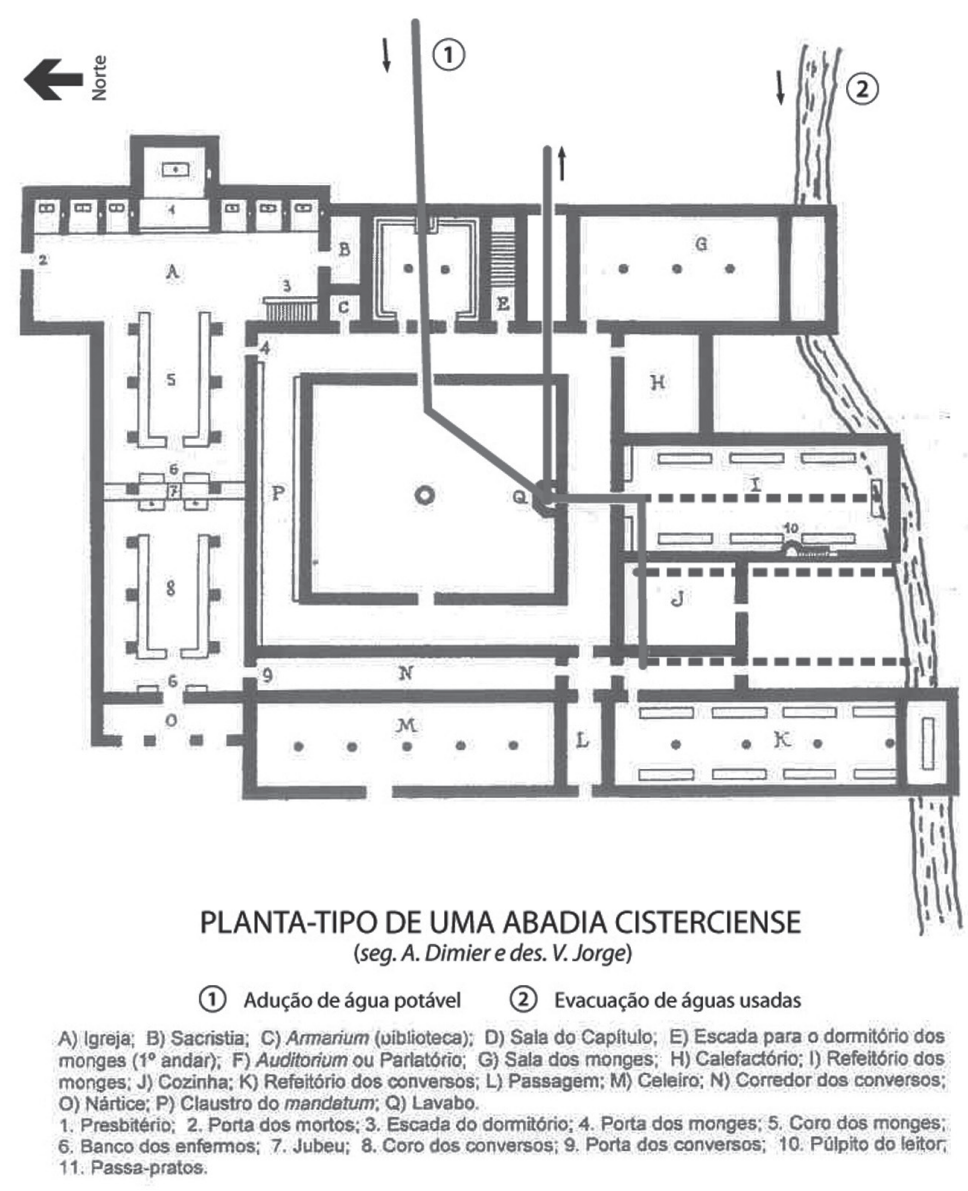

Fig. 1 - Abadia Cisterciense Medieval. Planta-tipo.

Des. Virgolino Jorge

ribeiro ou da levada ${ }^{8}$. Como notamos, o referido desenho apresenta não só a habitual disposição cisterciense da igreja e das dependências regulares anexas, mas também o traçado hídrico indispensável de apoio às instalações conventuais. Uma canalização assegura o abastecimento de água potável ao lavatório do claustro e aos espaços necessitados do cenóbio (cozinha, zona dos conversos,

\footnotetext{
8 Por vezes, as especificidades do sítio (nível freático alto, terrapleno, etc.) obrigaram a fundações de paredes sobre arcadas, pela sua capacidade de deformação elástica, a fim de evitar aluimentos ou subsidências e assegurar a estabilidade dos edifícios. Esta técnica construtiva foi utilizada no Mosteiro de Tarouca.
} 
enfermaria, etc.), enquanto o outro fluxo atravessa inferiormente as latrinas e os refeitórios dos monges e dos conversos, recolhendo e transportando as matérias fecais, as lavaduras e os esgotos para o exterior da cerca ${ }^{9}$. Uma ramificação artificial, efectuada a montante desta corrente, fornece também água para os viveiros piscícolas ${ }^{10} \mathrm{e}$ para o funcionamento das diversas estruturas técnicas da abadia, como moinhos, azenhas, pisões, noras e outras oficinas mecânicas ${ }^{11}$. Os mosteiros de Tarouca e de Alcobaça, entre outros, documentam e ilustram esta antiga observância, de modo exemplar e com significado nacional. A existência de um sistema de concepção similar noutras casas da Ordem é um pressuposto aceite, quando faltam ou subsistem escassos testemunhos das suas instalações hidráulicas primitivas, destruídos por obras e ampliações posteriores (em Alcobaça, por exemplo - Fig. 2). Admite-se alguma diversidade ou até inovação possíveis nas soluções alternativas preconizadas para o traçado dos seus caminhos da água, decorrentes das particularidades oridrográficas dos sítios e das consequentes opções pelos programas habituais de construção dos edifícios cistercienses ${ }^{12}$.

As comunidades do ramo feminino da Ordem procuraram, de igual modo, a proximidade da água para os seus gastos domésticos quotidianos e fins agrícolas. Mas, ao contrário das congéneres masculinas, as monjas viviam em rigorosa clausura e não exploravam directamente estruturas industriais, pelo que não dominavam o saber técnico da força hidráulica, como potencial fonte de energia. Assim se compreendem melhor as condições topográficas e agro-ambientais, por vezes ásperas e inclementes, que singularizam certos espaços ocupados por estes cenóbios medievos (os nomeados habitats em encosta), com frequência afastados de cursos de água permanente ou de caudal

9 Em Alcobaça, na face interna do paredão norte da antiga sala dos monges ou scriptorium (piso térreo) e do seu dormitório primitivo (andar superior), ainda se distingue o recorte da entrada nas respectivas instalações sanitárias, destruídas com as obras tardimedievais de expansão do mosteiro.

10 O regime alimentar dos monges cistercienses era muito frugal e anticarnívoro de quadrúpedes. Compunha-se, sobretudo, por peixe, hortaliça, fruta, pão e vinho (este limitado pela Regra, no capítulo XL, 3, ao consumo diário de uma hemina, ou seja, cerca de 1/4 de litro). A título de excepção, a carne estava permitida na dieta dos monges enfermos graves (capítulo XXXIX, 11 da Regra).

${ }_{11}$ A este propósito, veja-se Charles Hetzlen e René De Vos (eds.), Monachisme et technologie dans la société médiévale du Xe au XIIIe siècle, Cluny, Ecole Nationale Supérieure d'Arts et Métiers, 1994.

12 De ordinário, a resolução eventual e pontual destes problemas constituiu mais um modo de execução adaptada do que uma evolução tecnológica. 


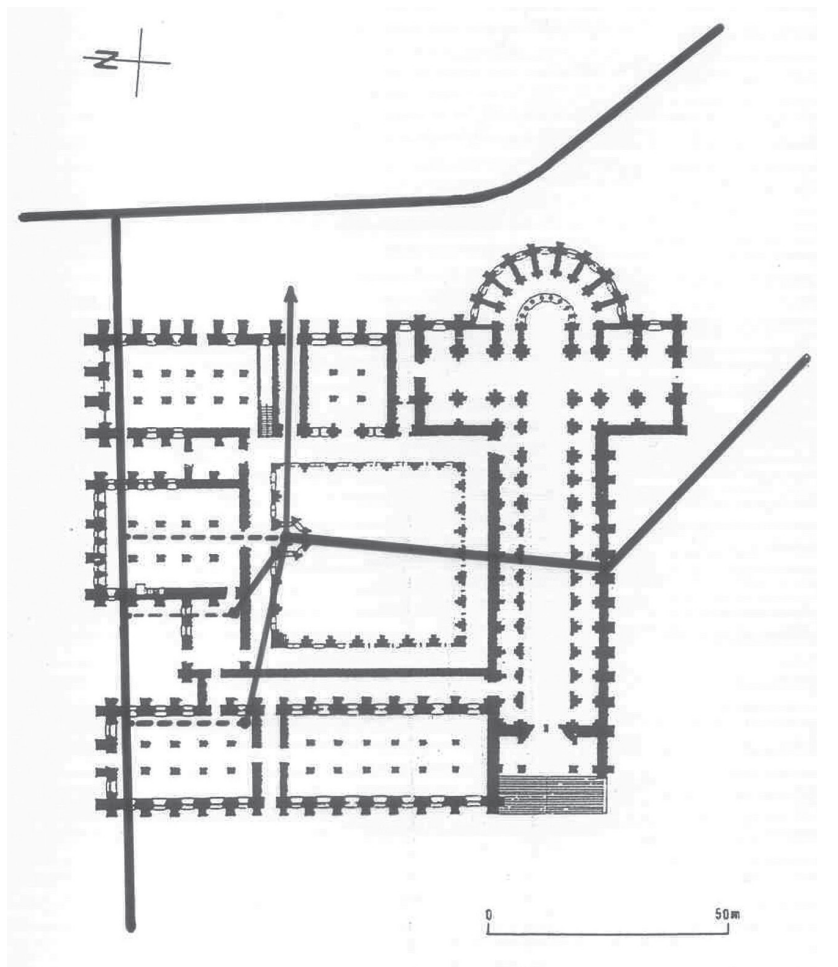

\section{Abadia Cisterciense de Alcobaça \\ Rede Hidráulica (reconstituição) \\ Rede de adução de água potável \\ Rede de distribuição de água potável \\ _...Canal de evacuação}

Fig. 2 - Alcobaça. Abadia Cisterciense. Rede hidráulica (reconstituição).

Des. Virgolino Jorge

apreciável (vejam-se os característicos exemplos dos mosteiros de Portalegre ${ }^{13}$, Cástris ${ }^{14}$ ou Celas). O cumprimento da vida ascético-contemplativa reclusa foi o objectivo primário para a justificação e existência daquelas implantações,

13 Sobre as captações de água no Mosteiro de Portalegre, ver Domingos Almeida Bucho, Mosteiro de São Bernardo de Portalegre, Évora, D. Bucho, 1995, p. 116 e anexos XIV-XVII.

14 Acerca da rede hidráulica do Mosteiro de Cástris, ver Elsa Caeiro, António Borges Abel e José Manuel Mascarenhas, “Os sistemas hidráulicos da Abadia de São Bento de Cástris (Évora): Reconhecimento e análise preliminar", em José Manuel Mascarenhas, Maria Helena Abecasis e Virgolino Ferreira Jorge (eds.), Hidráulica Monástica Medieval e Moderna, cit., p. 209-226. 
algumas de patronato nobiliárquico ${ }^{15}$. A escassez hídrica local obrigou à abertura de poços e à construção de cisternas ou de tanques e de bacias de retenção, destinados à exploração e à recuperação e armazenamento de águas, em face dos usos e necessidades elementares a suprir próprios do dia-a-dia comunitário.

Os monges de Cister ensinaram-nos a conquistar e a domesticar a água, não só como ela se regula, mas também como se capta, transporta, armazena, utiliza e gere com racionalidade e eficiência. A água foi a fonte da vida e do seu crescimento e estímulo económico e o zelo beneditino-cisterciense de o monge "viver do trabalho das suas mãos [e] do cultivo das terras" converteu a antiga fidelidade à Regra e ao lugar de profissão em incongruente riqueza senhorial ${ }^{16}$. Em suma e na amplitude das suas manifestações concretas, a história do monasticismo cisterciense medieval é também uma história da relação estreita e longa do homem com a água. Dois elementos de estudo tão extensos como significativos, na sua acepção e importância religiosa, cultural, socioeconómica e ambiental.

\section{Gestão dos Recursos Hídricos}

O mantimento geral de um mosteiro cisterciense de outrora requeria grandes volumes de água diários e cuidadosos trabalhos de reparação e limpeza das estruturas e equipamentos hidrotécnicos associados, como fontes, condutas e canais, que garantissem a sua eficácia e durabilidade. Porém, este assunto está ausente ou emerge de modo acidental e elíptico na documentação histórica conhecida dos fundos da Ordem, dificultando o seu esclarecimento plausível e a aplicação de uma cronologia prática fidedigna. Talvez porque se perdeu ou porque os Cistercienses subestimassem estas obras de aproveitamento e conservação das águas e dos dispositivos atinentes como rotinas simples e normais da conventualidade, dispensáveis de especial registo escrito ${ }^{17}$. Os monges necessitavam de aprovisionamento de água corrente e constante,

15 Cf. Virgolino Ferreira Jorge, "Monastères cisterciens de femmes au Portugal. Note sur la typologie des sites et des églises", em Bernadette Barrière e Marie-Elizabeth Henneau (eds.), Cîteaux et les femmes, Paris, Créaphis, 2001, p. 73-81 (tradução portuguesa: "Mosteiros Cistercienses Femininos em Portugal. Notas sobre a tipologia dos sítios e das igrejas", Boletim Cultural da Assembleia Distrital de Lisboa, 94-2 (2000-2002), p. 5-16.

16 Para a consulta dos estatutos anteriores a 1134, ver Cister. Documentos Primitivos (introdução, tradução e notas de Aires A. Nascimento), Lisboa, Colibri, 1999, p. 81-85.

${ }_{17}$ Consultar Saul António Gomes, Visitações a Mosteiros Cistercienses em Portugal. Séculos XV e XVI, Lisboa, IPPAR, 1998. 
para os usos potáveis e comuns, tanto no espaço domiciliário como na periferia dos seus edifícios. Era mister satisfazer os vários propósitos e carências básicas da vida quotidiana cenobítica, desde o consumo humano directo de água até ao seu uso como importante fonte de energia, passando pela sua utilização para a saúde e higiene corporal, cocção, limpezas e lavagens domésticas, trabalhos de produção agrícola e piscícola, comunicações e transporte, consumo animal, etc., a recapitular:

- fins domésticos (cozinhar, dessedentar, higiene pessoal e outras abluções);

- piscicultura (destinada ao consumo pela comunidade);

- tarefas agrícolas (criação de animais e irrigação fundiária);

- actividades industriais (accionamento de forjas, moinhos, noras, etc.);

- saneamento de latrinas.

Acerca do emprego disciplinado da água, a Regra Beneditina enuncia algumas indicações precisas quanto aos banhos e outras lavagens comunitárias. Recomendam-se banhos higioterapêuticos (cura aquarum) aos monges enfermos e convalescentes, sempre que necessários à sua saúde corporal ${ }^{18}$. Para a restante comunidade, sobretudo aos irmãos mais novos, só ocasionalmente era tolerado banharem-se (capítulo XXXVI, 8 da Regra). A observância da higiene pessoal, como uma necessidade ou hábito sanitário, era pouco apreciada e limitava-se ao mínimo de limpeza, ou seja, à lavagem simples das mãos, antes e depois das refeições colectivas ${ }^{19}$, do rosto e do rito semanal do lava-pés (a cerimónia do mandatum, no corredor do claustro anexa à igreja $\mathrm{a}^{20}$ ). Uma lavação completa (com água quente?) era interpretada como uma busca ou motivo de conforto e volúpia pecaminosa, pelo que foi desencorajada e de acto excepcional, ocorrendo só em importantes festividades litúrgicas (normalmente, pelo Natal, Páscoa ou Pentecostes) $)^{21}$.

18 O termalismo e o conceito dos actuais Fitnesscenter e SPA assentam no cultivo e na valorização do corpo e da saúde, mediante as qualidades tradicionais da hidriatria.

19 Até ao uso habitual dos talheres, comia-se com os dedos das mãos, de modo que tais abluções se justificavam como cuidados elementares de higiene. Este preceito do lava-mãos foi suprimido somente pelo Concílio Vaticano II (1962-1965).

20 Acerca deste mandato, cf. Regra de São Bento, capítulo XXXV, 9.

21 Há quem defenda esta restrição do banho como um imperativo de mortificação corporal. A este propósito, consultar Reginald Reynolds, Cleanliness and Godliness, Londres, George Allen \& Unwin, 1946, ou Meredith Parsons Lillich, "Cleanliness with godliness: a discussion of medieval monastic plumbing”, em Benoît Chauvin (ed.), Mélanges à la mémoire du Père Anselme Dimier, vol. III-5, Pupillin/Arbois, B. Chauvin, 1982, p. 123-149. A documentação cisterciense mais antiga refere-se aos banhos, unicamente devido a transgressões e escândalos 
Ainda a propósito da indiferença pelo asseio individual ou "horror ao banho" higiénico, recorda-se que os conversos, a quem estavam confiadas as tarefas diárias mais pesadas do trabalho monástico e habitavam zonas separadas no cenóbio, não tinham acesso regular ao lavatório ou à fonte do claustro. Por outro lado, também nem a citada planta-esquema do mosteiro cisterciense medieval o previa nem foram encontrados balneários ou casas de banho daquela época, em ancestrais estabelecimentos da Ordem.

De acordo com o mencionado normativo beneditino, em praxe hospitaleira de replicação romana ${ }^{22}$, o abade devia aspergir com água as mãos dos hóspedes do mosteiro e, com a colaboração do convento, lavar-lhes os pés (Regra, capítulo LIII, 12-14).

Ao sábado, os monges que iniciavam e os que finalizavam o serviço semanal à cozinha lavavam os pés de todos os irmãos (capítulo XXXV, 9 da Regra).

\section{Rede Hidráulica Geral}

Até que o encanamento de água potável corrente ao mosteiro estivesse superado por mananciais próprios, a fraternidade era abastecida, através de uma adução manual, por água nativa extraída directamente de cursos a céu aberto, de fontes ou de poços escavados no precinto cenobítico, aproveitando o nível freático do lugar. Nos seus inícios, esse processo rudimentar e único bastava aos gastos e às necessidades primárias quotidianas do "acampamento" abacial, mas não respondia às exigências ulteriores de um mosteiro em pleno crescimento demográfico, ou seja, à satisfação de um aumento dos consumidores de água. Por consequência, foi necessário proceder a trabalhos hidráulicos mais complexos de captação de água fresca em nascentes afastadas e trazê-la para o mosteiro, graças à construção de um conduto. O conhecimento prévio dos factores topográficos e hidrogeológicos do meio físico onde essas obras de exploração e transporte da água foram efectuadas revelou-se fundamental para o bom desempenho dos respectivos sistemas de abastecimento às comunidades religiosas.

praticados por alguns abades e monges, a quem foram aplicadas as respectivas penas capitulares (vejam-se as actas dos Capítulos Gerais dos anos de 1202, 1212, 1225, etc.). Cf. Joseph-Marie Canivez (ed.), Statuta Capitulorum Generalium Ordinis Cisterciensis ab anno 1116 ad annum 1786, vol. 1, Lovaina, Revue d'histoire eclésiastique, 1933.

22 Importa lembrar que o texto beneditino remonta ao $1^{\circ}$ terço do século VI. 
As estruturas hidráulicas definitivas de um mosteiro cisterciense obrigavam à construção de um duplo sistema, independente e com extensões e níveis de execução e dificuldade técnica distintos: um de aprovisionamento de água limpa aos lugares regulares (em canalização fechada) e outro, de condução de água comum e usada (hoje, dizemos águas poluídas), para accionar moinhos e forjas, irrigação de terrenos, saneamento de latrinas, etc. (em canal aberto). Podemos esquematizar essas redes em dois grupos essenciais, que têm origens, ciclos e finalidades hidráulicas diferenciados, mas de coerência complementar, adequados à natureza da utilização das águas e à qualidade bacteriológica exigida, a saber (Fig. 3):

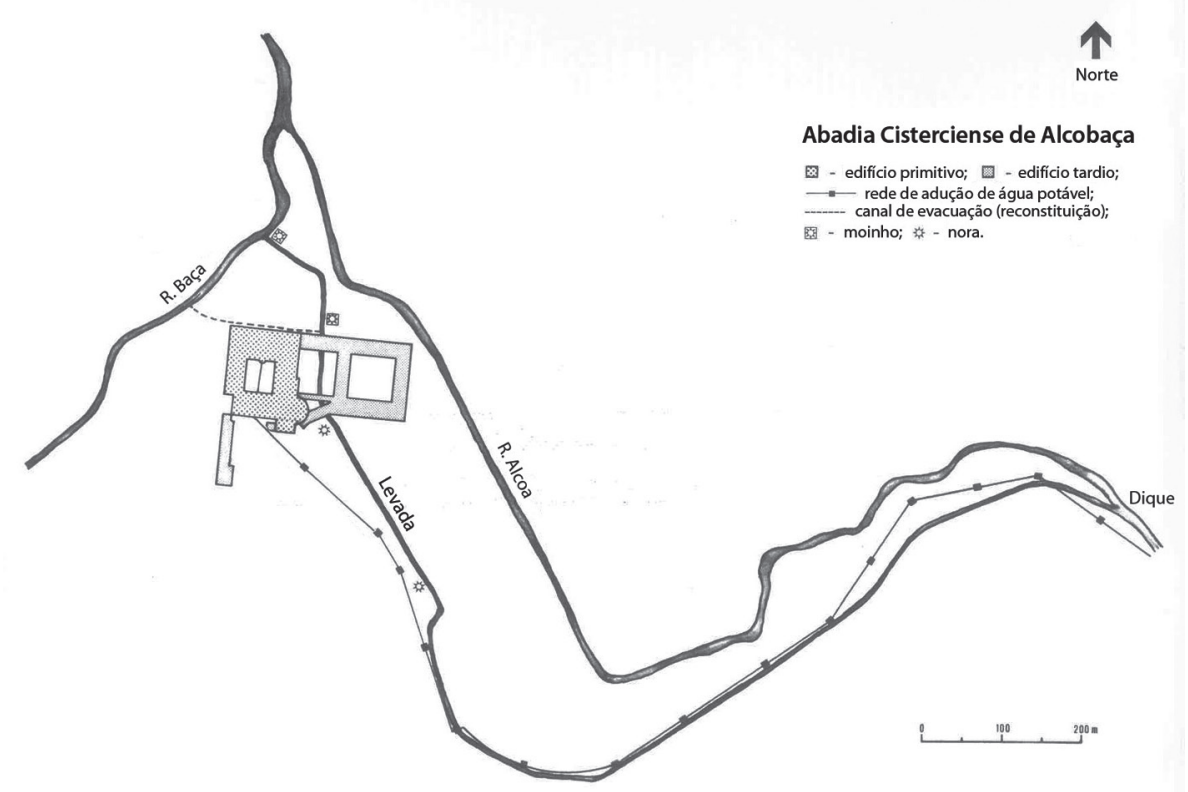

Fig. 3 - Alcobaça. Abadia Cisterciense. Obras de ordenamento hidráulico.

Des. Virgolino Jorge

\section{Rede de água potável}

Captação (minas ou poços);

Transporte (canalização fechada);

Armazenamento (cisternas ou tanques);

Distribuição (lavatório ou fonte, cozinha, zona dos conversos e enfermaria). 


\section{Rede de água comum e usada}

Captação (rio ou ribeiro);

Transporte (geralmente, através de levada);

Distribuição (usos industriais, actividades agrícolas e produção piscícola);

Descarga (sobras do lavatório ou da fonte e esgotos doméstico, fecal e pluvial).

No contexto do sistema hidráulico de uma abadia medieval de Cister, as tarefas que ofereceram maiores embaraços de operação, quer pelos meios materiais e recursos humanos envolvidos quer pelos erros e correcções necessárias a alguns trabalhos efectuados, foram, sem dúvida, as relativas à captagem de águas potável e comum e ao seu transporte para o abastecimento das zonas residencial e agrícola confinante. Daí que estes aspectos, entre outros que se prendem e limitam as necessidades imediatas do quotidiano comunitário monástico, suscitem interesse e careçam de uma análise mais demorada no quadro deste estudo conciso.

\section{Captação de Água Potável}

A compreensão minuciosa e variada das características hidrogeológicas dos lugares, tanto do ponto de vista da detecção e pesquisa das águas subterrâneas como das superficiais, pressupunha competências específicas do vedor e dos mineiros. Com efeito, a disponibilidade de água salubre em débito suficiente e perene e com boa composição química radica numa estrutura geomorfológica favorável à constituição desses lençóis aquíferos e olhos-d'água ${ }^{23}$.

O êxito ou o fracasso do fornecimento de água captada aos antigos mosteiros resultavam dessa arte e capacidade hidrognomónica pessoal e de uma resposta prévia, satisfatória e conjunta aos quesitos de execução prática associados à sua planificação, da qual eram tributárias também a solidez e a funcionalidade do sistema de transporte a jusante das captações, a formular:

- que métodos adoptavam os Cistercienses, para escolher as áreas mais adequadas à prospecção de veios ou fontes naturais e avaliar a sua pureza, abundância e profundidade freática?

23 Acerca de modos e técnicas antigos de captação de água potável, veja-se José Manuel Mascarenhas, Paul Benoit, Karine Berthier, Joséphine Rouillard e Virgolino Ferreira Jorge, "Comparative analysis of mines supplying water to towns, to abbeys and to manors in Portugal", Schriftenreihe der Frontinus-Gesellschaft, 26 (2005), p. 207-222. 
- como definiam o traçado linear do sistema adutor, em face dos acidentes do terreno e da distância até aos mosteiros (de montante para jusante e num comprimento variável entre centenas de metros a quilómetros $\left.{ }^{24}\right)$ ?

- para o cálculo da pendente geral da conduta e garantia do declive médio e ajustado ao longo do seu trajecto de escoamento, que ferramentas de trabalho e processos artesanais ou normas técnicas em vigor utilizavam?

A referida aptidão de leitura da natureza orgânica dos solos constituía, em simultâneo, uma mais-valia quanto à notícia das zonas de interesse qualificadas para extrair matéria rochosa destinada às obras de construção do estabelecimento cisterciense.

O local das antigas nascentes está abrigado por uma pequena e singela construção, em regra de planta quadrada ou rectangular, onde se acumulam e decantam as ressurgências emanadas das minas, antes de se introduzirem no aqueduto ${ }^{25}$ para o mosteiro (Figs. 4-8). Estas casas-d'água encontram-se, amiúde, semienterradas, visualmente despercebidas, bem conservadas e completas na sua disposição primitiva e, ainda hoje, em farta actividade caudalosa. Devido ao seu isolamento, costumam dar o nome à área limítrofe dessas antigas captações (refiram-se microtopónimos como Arca-d'Água, em Tarouca, Fonte dos Frades, em Lafões, etc. ${ }^{26}$.

\section{Transporte de Água Potável}

A condução da água limpa entre os dois pontos fixos do sistema, ou seja, entre o reservatório da nascente e o do terminal de descarga da conduta no

${ }^{24}$ Por exemplo, em Tarouca $(0,280 \mathrm{~km})$, Lafões $(1,200 \mathrm{~km})$ e Alcobaça $(3,280 \mathrm{~km})$. Cf. Virgolino Ferreira Jorge, “Análise Preliminar das Estruturas Hidráulicas da Abadia Cisterciense de São João de Tarouca (Portugal)", Actas del II Congreso Internacional sobre el Císter en Galicia y Portugal, vol. III, Ourense, Ed. Monte Casino, 1998, p. 1407-1420; Carlos Correia Dias e Virgolino Ferreira Jorge, "Rede Hidráulica da Abadia Cisterciense de São Cristóvão de Lafões (São Pedro do Sul)", em José Manuel Mascarenhas, Maria Helena Abecasis e Virgolino Ferreira Jorge (eds.), Hidráulica Monástica Medieval e Moderna, cit., 1996, p. 227-240; e Virgolino Ferreira Jorge, "Captage, Adduction, Distribution et Évacuation de l'Eau dans l'Abbaye Cistercienne d'Alcobaça (Estremadure, Portugal)", em Léon Pressouyre e Paul Benoit (eds.), L'hydraulique monastique. Milieux, réseaux, usages, cit., p. 221-233.

25 Do ponto de vista etimológico, "aqueduto" significa condução de água (aquae ductus). É, portanto, errado identificar e restringir o vocábulo a uma ponte sobre arcos, a qual constitui tão-só um trecho parcial aéreo e emblemático desse traçado adutor ('ponte-aqueduto', do latim aquae ductus structilis), sobre a qual assenta o ducto da água.

26 Sobre vocábulos hidronímicos, consultar Joseph M. Piel, “As águas na toponímia galego-portuguesa”, Boletim de Filologia, VIII-4 (1947), p. 305-342. 


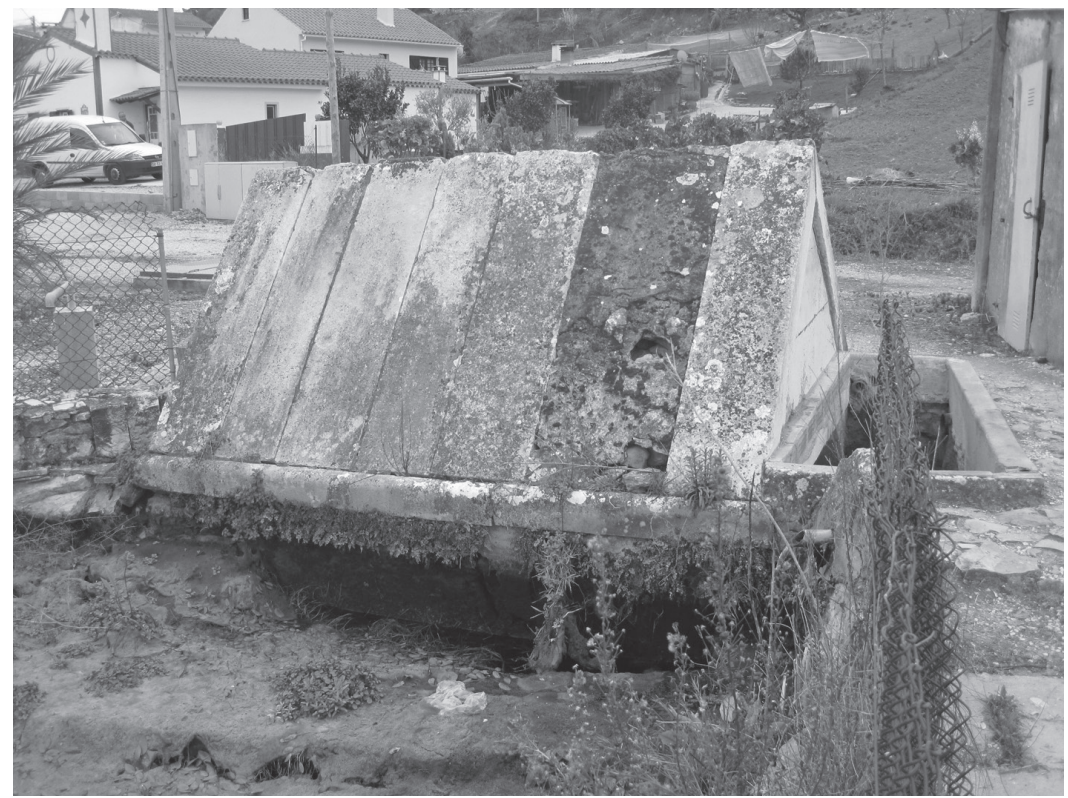

Fig. 4 - Alcobaça. Abadia Cisterciense. Captação de água potável na Chiqueda de Cima. Fotog. Virgolino Jorge

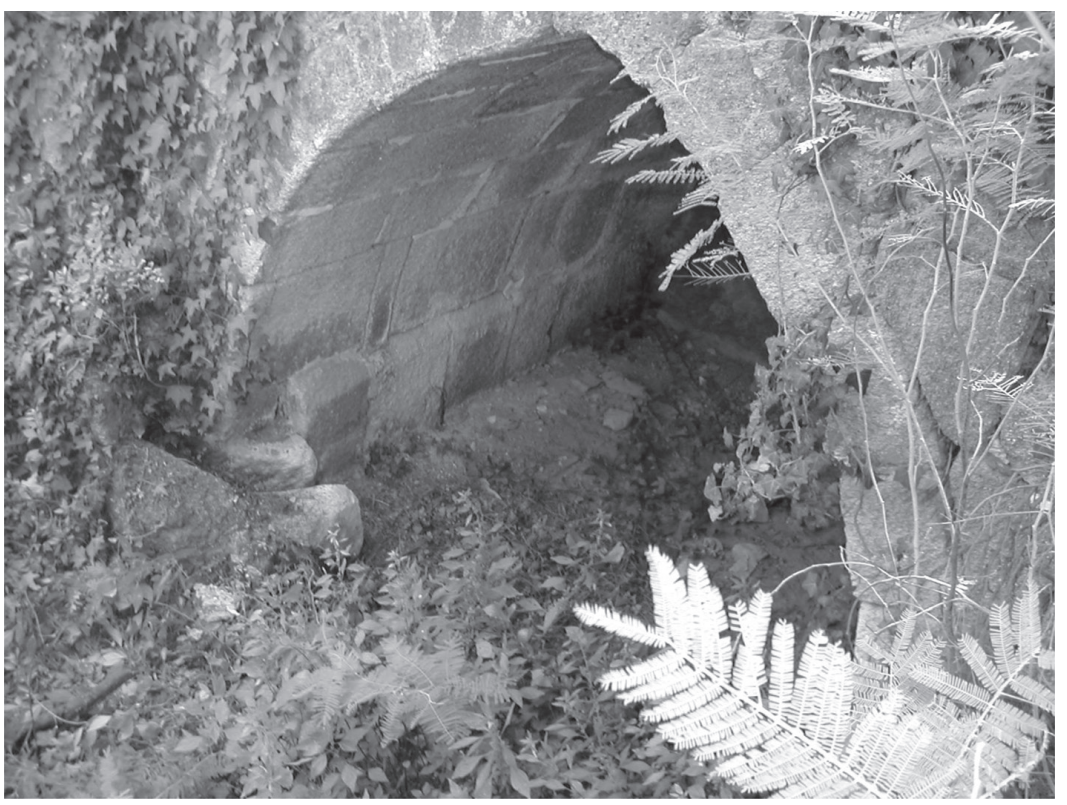

Fig. 5 - Águias. Abadia Cisterciense. Antiga mina de água potável. Fotog.Virgolino Jorge 


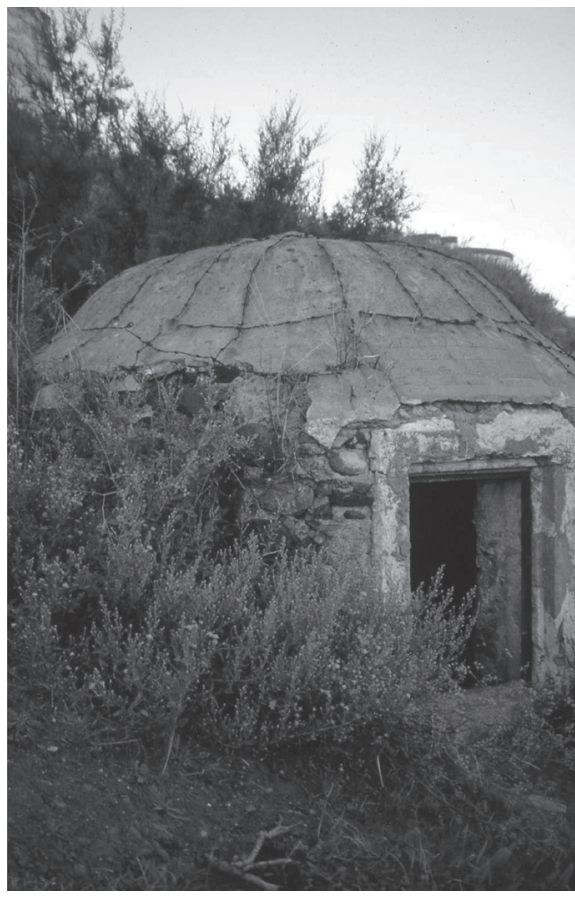

Fig. 6 - Odivelas. Abadia Cisterciense. Nascente do Casal Ventoso. Fotog.Virgolino Jorge

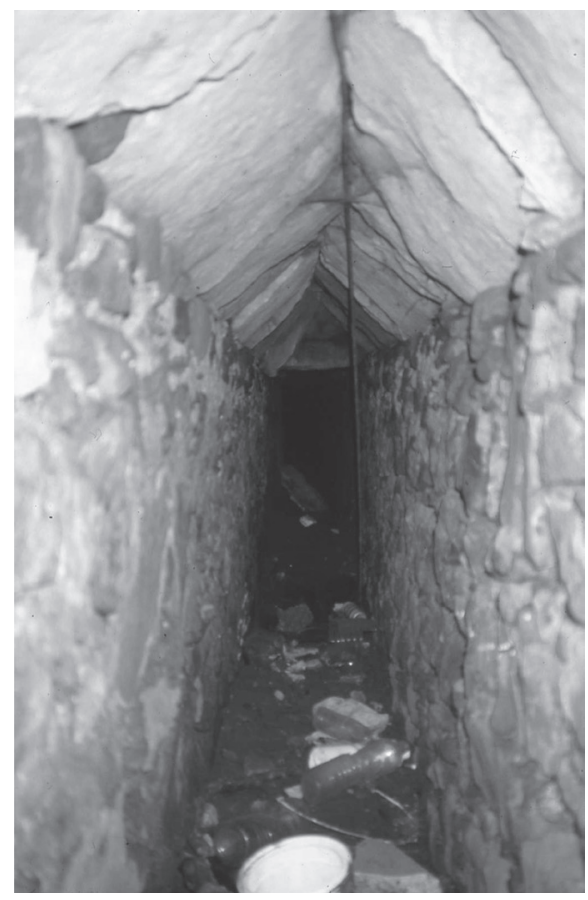

Fig. 7 - Odivelas. Abadia Cisterciense. Corredor da mina do Casal Ventoso. Fotog. Virgolino Jorge

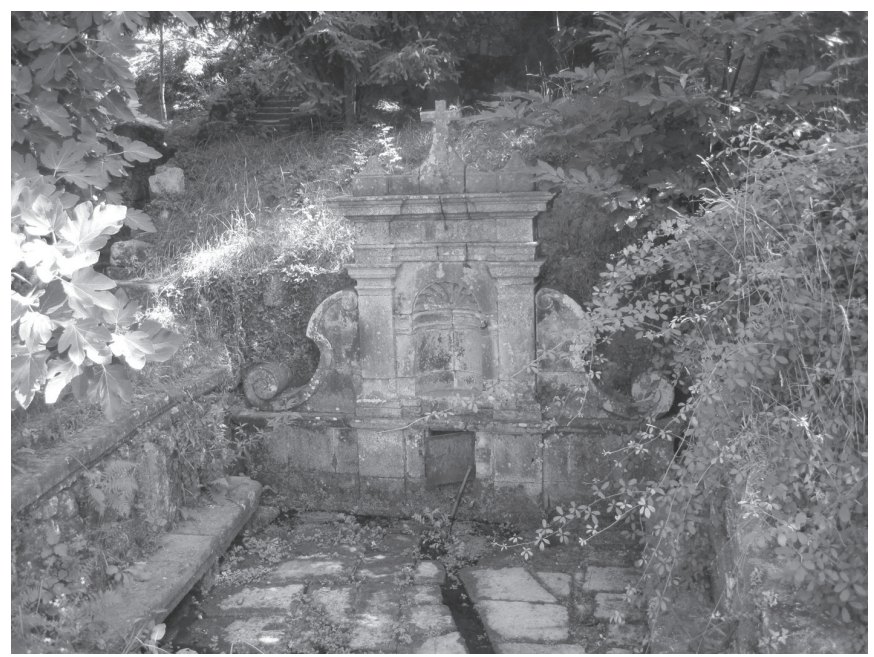

Fig. 8 - Arouca. Mosteiro Cisterciense. Nascente de água potável. Fotog.Virgolino Jorge 
mosteiro, processava-se por efeito da gravidade, explorando a fisiografia intermédia dos sítios.

O contexto topográfico determinava a resposta tecnológica do traçado adutor, nomeadamente a sua implantação, o declive total do aqueduto e os métodos e preceitos construtivos adaptados às exigências e à estabilidade necessárias ao trânsito normal da água. Sempre que possível, o alinhamento é rectilíneo. Acompanha ou aproxima-se das curvas de nível das áreas atravessadas, a fim de vencer o seu percurso com uma inclinação baixa e equilibrada e evitar velocidades de fluxo prejudiciais ao funcionamento hidráulico e à conservação da conduta (Fig. 9). Todavia, por razões de irregularidade morfológica do terreno, o seu perfil longitudinal nunca é constante em toda a extensão do trajecto, pelo que o regime de escoamento é variável entre a mãe-d'água e a chegada do fluido ao cenóbio.

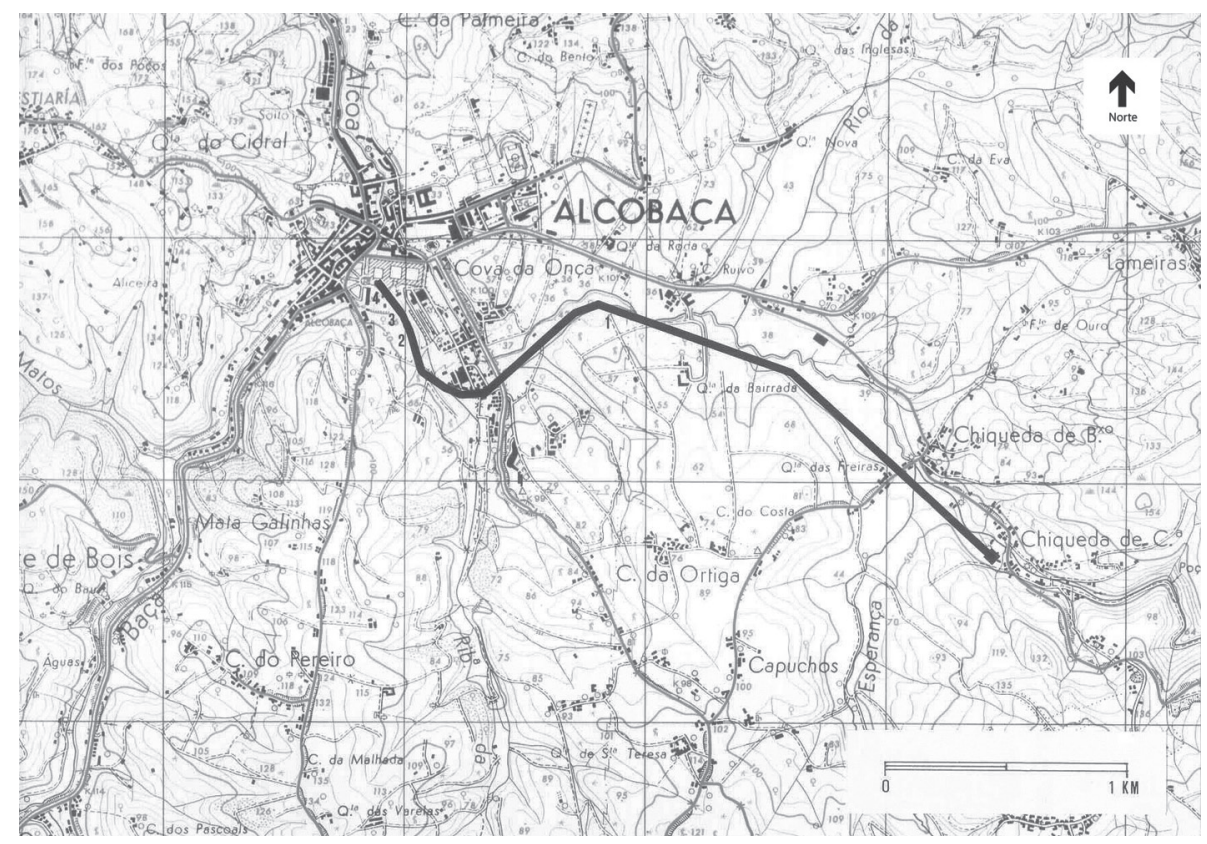

Fig. 9 - Alcobaça. Abadia Cisterciense. Traçado da adução de água potável. Des. Virgolino Jorge

De acordo com as condições geográficas locais favoráveis à adução prática da água, o assentamento da conduta fazia-se por segmentos subterrâneos, à superficie ou aéreos. As caleiras foram previamente aparelhadas, para garantirem o seu apoio e imobilização estáveis, têm dimensões rectangulares e 
cortes padronizados (blocos de calcário ou de granito, com valores próximos de $\mathrm{c} \times 1 \times \mathrm{h}=1,10 \times 0,36 \times 0,23 \mathrm{~m})$ e as extremidades unidas em série por um encaixe macho-fêmea (Fig. 10). A cobertura é feita com lajes móveis de idêntico material, excepto nos troços em galeria, onde as calhas estão abertas e instaladas no leito do corredor. O preenchimento das juntas e a união das tampas fazem-se com uma argamassa "hidráulica", isto é, forte e impermeável à água, que assegura a estanqueidade da conduta e evita fugas hídricas por rotura, além de impedir a entrada de vegetação no aqueduto.

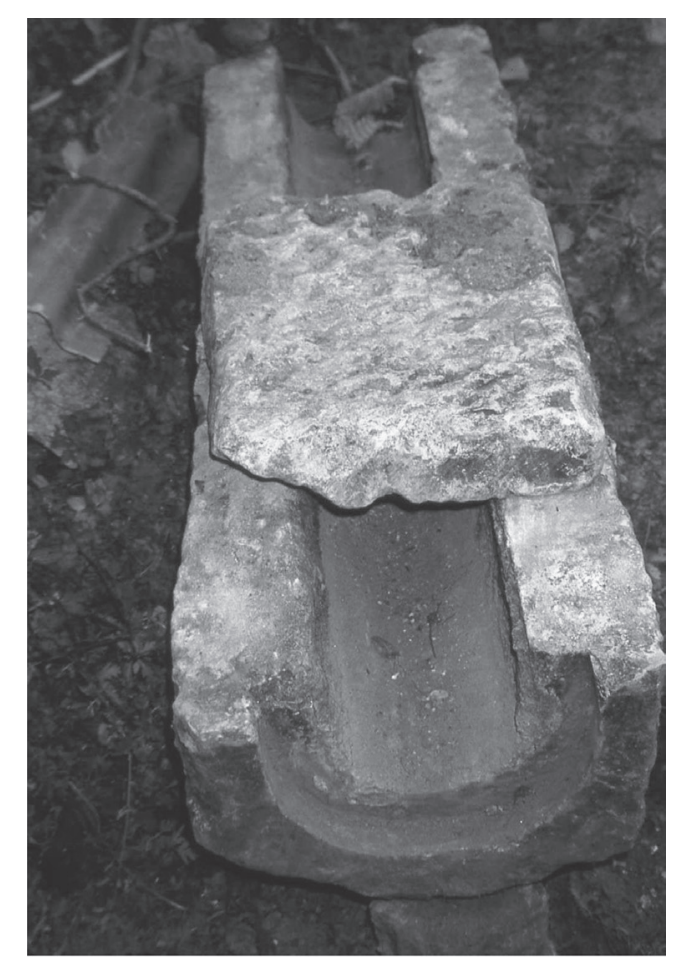

Fig. 10 - Alcobaça. Abadia Cisterciense. Caleira com secção transversal em $U$. Fotog. Virgolino Jorge

Em áreas de campina ou de relevo moderado, o canal está enterrado ou implantado à superfície (Figs. 11-12). Por vezes, certos constrangimentos formais obrigaram a inflectir o trajecto da conduta ou à realização de obras de arte, como exemplificam a abertura de galerias em trincheira e de túneis ou a construção de pontes. 


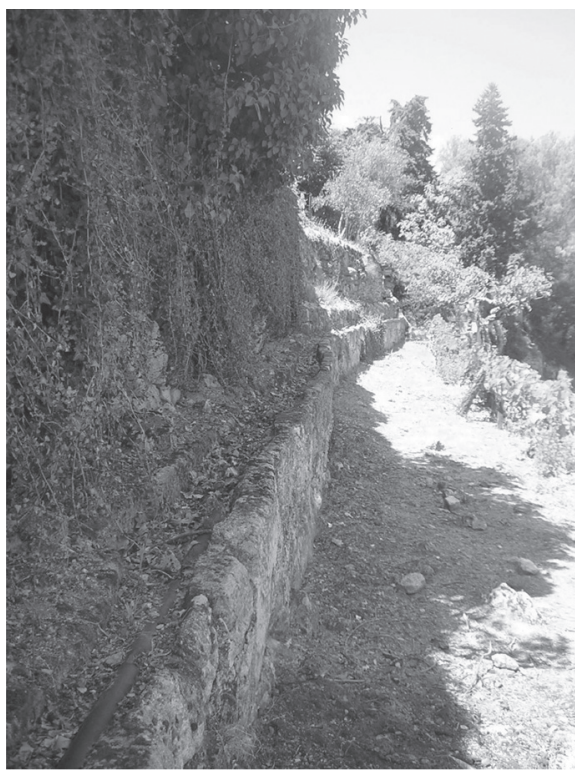

Fig. 11 - Águias. Abadia Cisterciense. Troço superficial de adução de água potável. Fotog. Virgolino Jorge

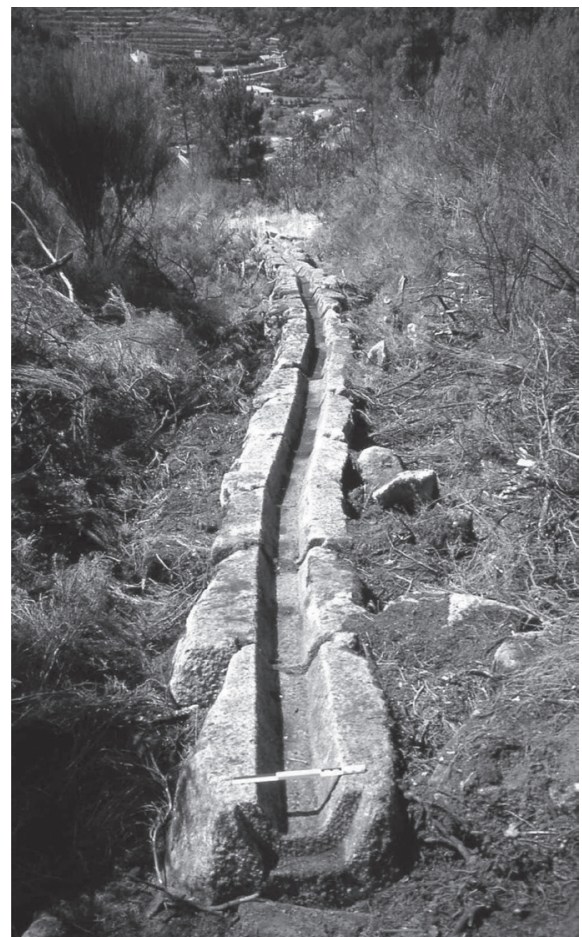

Fig. 12 - Tarouca. Abadia Cisterciense.

Troço superficial de adução de água potável (Quinta do Lavatório). Notar a secção transversal da caleira em V aberto. Fotog. Virgolino Jorge

Quando havia uma subida altimétrica do terreno, escavou-se uma vala em trincheira (Figs. 13-14) ou um túnel, a fim de manter o itinerário e a circulação gravitacional da água, ao longo daquela passagem ${ }^{27}$.

O transporte hídrico podia obrigar também à construção de trechos levantados, assentes sobre muros ou arcadas (aqueduto elevado ou ponteaqueduto), para cruzar rios e quebradas ou superar outros obstáculos da Natureza (Figs. 15-17).

Por vezes, o declive a vencer era excessivo ou o terreno apresentava-se socalcado. Para o efeito, concebeu-se um aqueduto em cascata ou escada ligadas

27 Sempre que possível, evitou-se a abertura de trechos do aqueduto em túnel, devido ao seu elevado custo e morosa execução. 


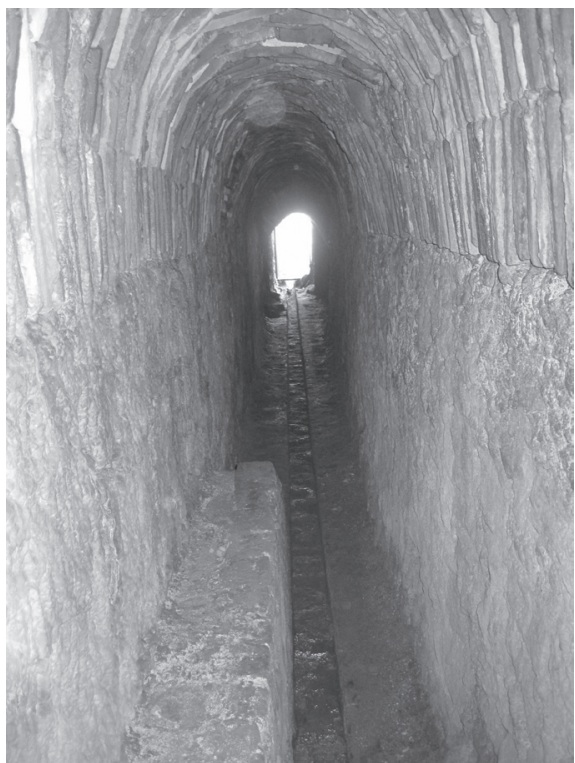

Fig. 13 - Alcobaça. Abadia Cisterciense. Troço subterrâneo de adução de água potável. Fotog. Virgolino Jorge

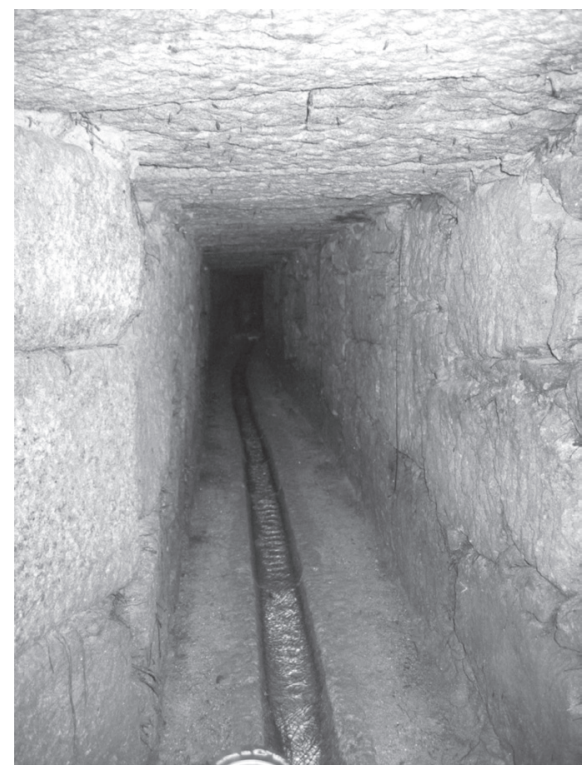

Fig. 14 - Lafões. Abadia Cisterciense. Canal subterrâneo de adução de água potável. Fotog. Virgolino Jorge

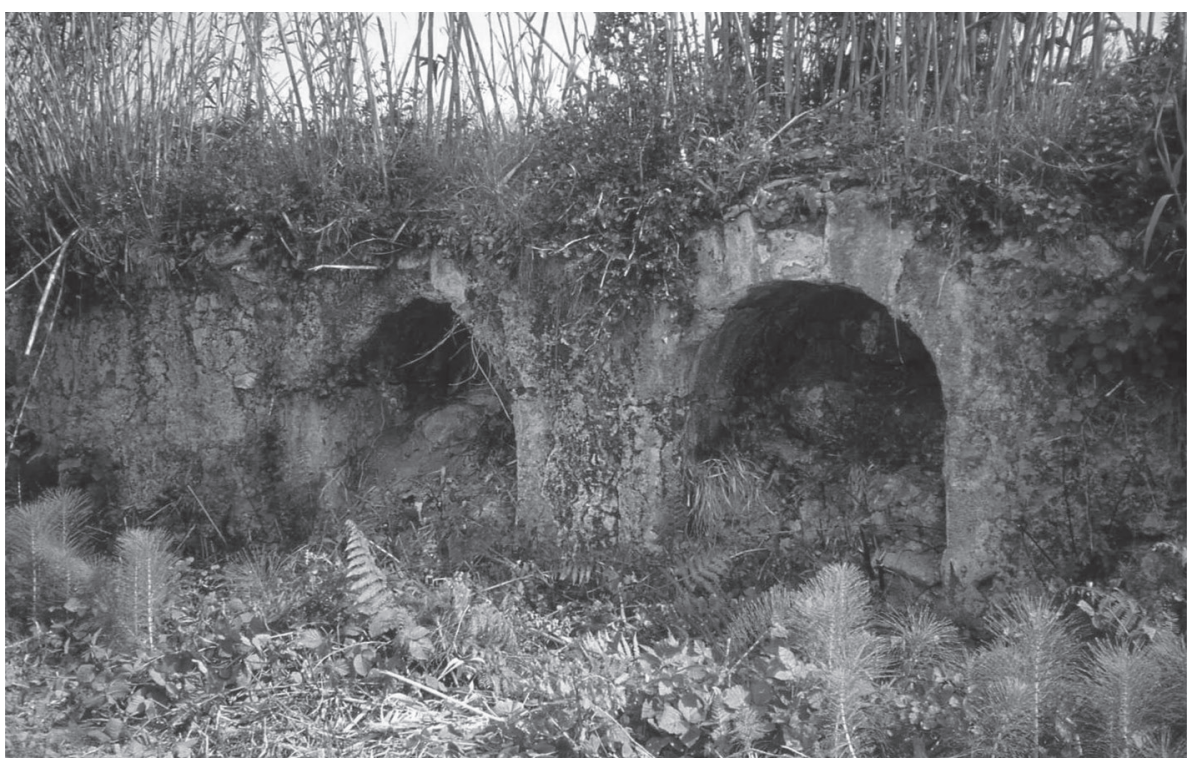

Fig. 15 - Alcobaça. Abadia Cisterciense. Troço aéreo de adução de água potável (destruído nos finais da $1^{a}$ década de 2000). Fotog. Virgolino Jorge 


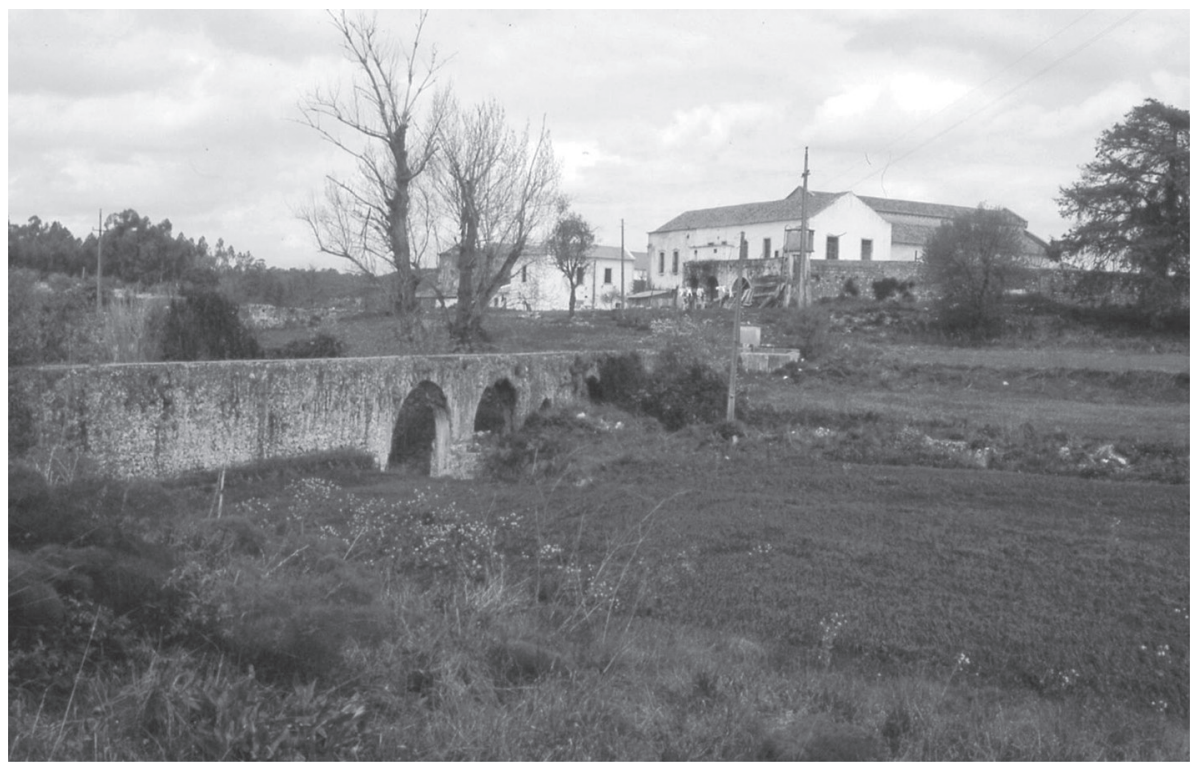

Fig. 16 - Almoster. Abadia Cisterciense. Troço aéreo de adução de água potável. Fotog. Virgolino Jorge

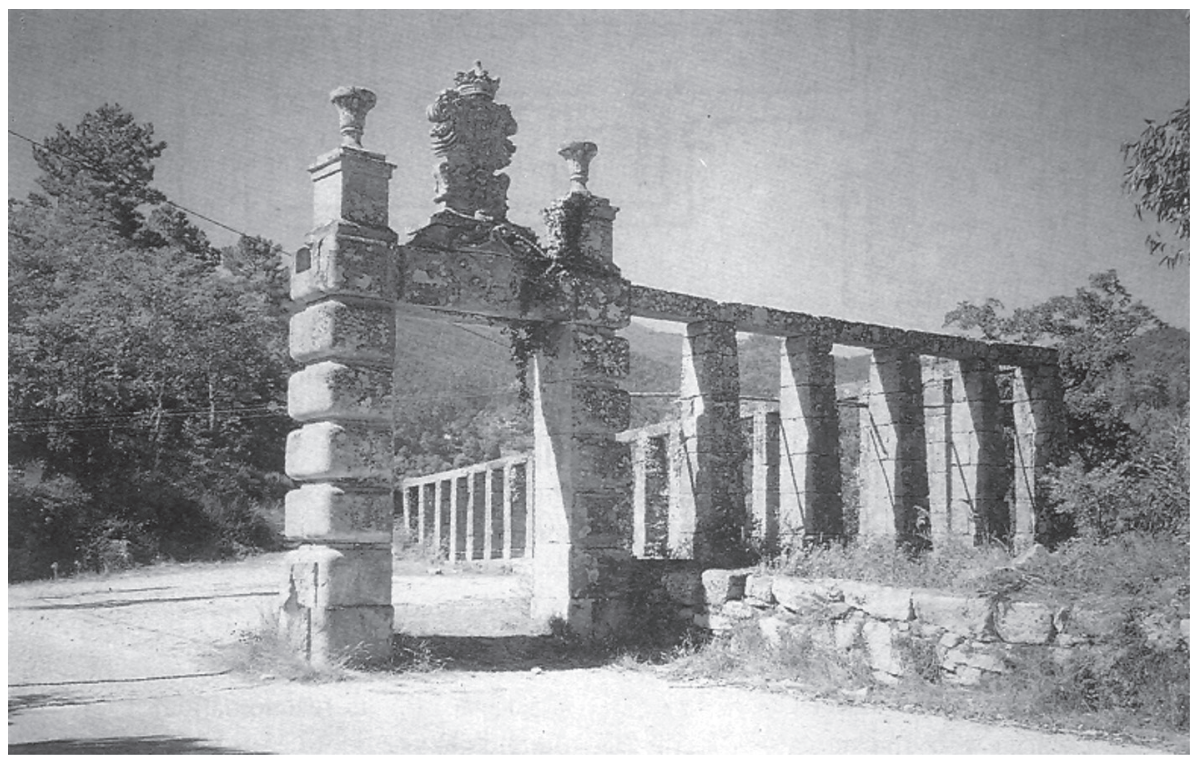

Fig. 17 - Lafões. Abadia Cisterciense. Troço aéreo de adução de água potável. Fotog. Virgolino Jorge 
por poços verticais, de profundidades variáveis. Com esta solução técnica, a água entrava superiormente e caía, perdia altitude, decantava-se e era travado o fluxo do sistema adutor, que continuava o seu rumo para jusante, saindo próximo da base do poço de queda (vejam-se Odivelas ou a adução medieval em Tarouca, esta com um desnível de cerca de 15,00 m, para um trecho linear de $0,280 \mathrm{~km}$, pois ajudam a elucidar este método engenhoso de transporte escalonado da água - Fig. 18).

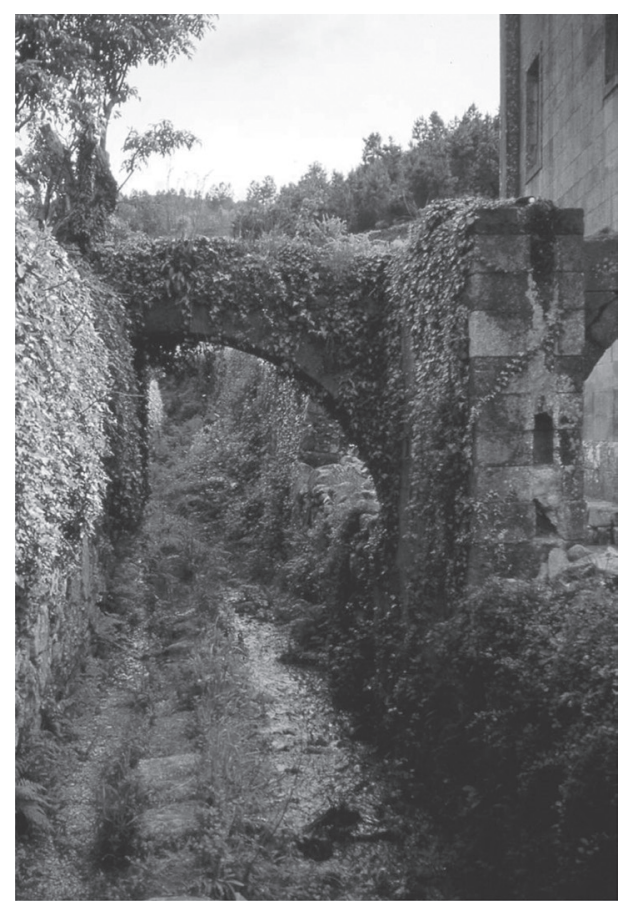

Fig. 18 - Tarouca. Abadia Cisterciense. Troço em escada de adução de água potável. Fotog. Virgolino Jorge

Os sedimentos arenosos e outras partículas arrastados pela água exigiam uma filtragem ou depuração, que era assegurada por pequenos receptáculos dispostos ao longo da conduta, aonde eles se depositavam e eram removidos periodicamente (Fig. 19). O afastamento entre estas caixas de sedimentação ou decantação é mais ou menos equidistante e foi estabelecido pelas características e modalidades do corredor hídrico (sinuosidade do traçado, inclinação do canal, etc.) 


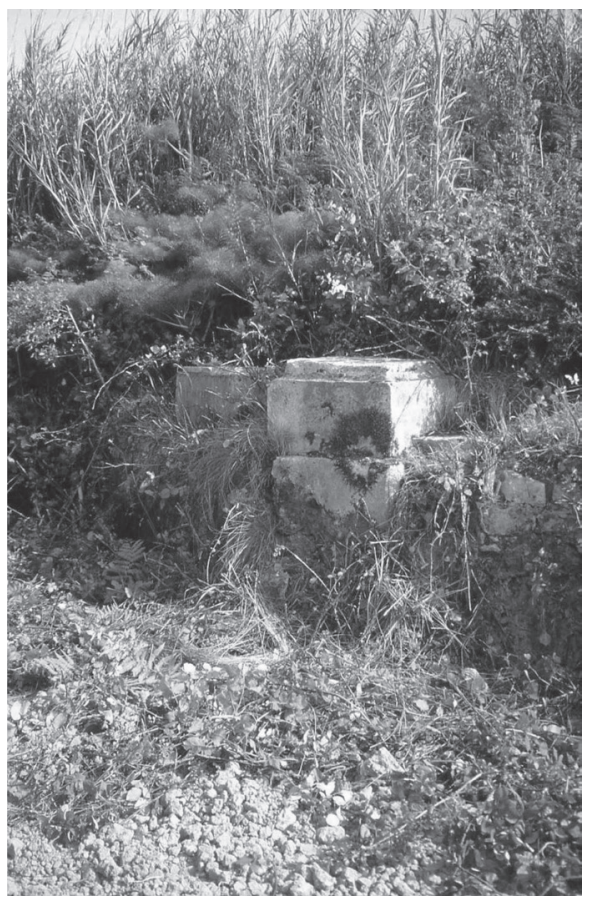

Fig. 19 - Alcobaça. Abadia Cisterciense. Transporte de água potável. Caixa de decantação. Fotog. Virgolino Jorge

Nos segmentos do aqueduto atravessados em galeria ou em túnel, construíram-se poços de visita que permitiam o acesso directo e fácil de pessoal ao interior, para efectuar as manutenções de rotina à conduta (na direcção oposta à da corrente), assegurando o seu rendimento hidráulico e a longevidade da $\mathrm{obra}^{28}$. Estas entradas verticais de inspecção e limpeza serviam também para

28 Tanto em galerias de transporte como noutras de captação ou de descarga, estas construções subterrâneas apresentam uma largura média de 0,75-0,85 m e um pé-direito variável entre 1,75-1,85 m. Quando se trata de trincheiras, estão cobertas com uma abóbada de pedra ou de cerâmica (em berço de pedra, em Tarouca, e de tijoleira com perfil côncavo, em Alcobaça e Almoster), com lajes pétreas planas (Alcobaça e Lafões) ou em V invertido (Odivelas). Se o corredor está emparedado, não existem problemas de desabamento nem a necessidade habitual de proceder a vistorias preventivas à conduta, pelo que a sua amplitude é quase sempre inferior àquelas dimensões (em Alcobaça, com 0,72 m de largura e 1,32 m de altura, e em Lafões, com 0,77 m de largura e 0,99 m de altura). Acerca destas estruturas e sistemas construtivos, nos mosteiros de Almoster e de Odivelas, consultem-se, respectivamente, José Manuel Mascarenhas e Virgolino Ferreira Jorge, "Le Système Hydraulique de l'Abbaye Cistercienne d'Almoster (Ribatejo, 
arejar, reduzir a pressão hidrostática e evitar o "enfarte" do aqueduto (daí, a designação popular de respiradouros ou ventiladores) $)^{29}$.

Ao alcançar o mosteiro, a viagem da água fazia-se para um tanque de compensação (Fig. 20). Desse recipiente, ela era conduzida para o lavabo ou fonte do claustro, em adução forçada, a fim de permitir a sua subida até à taça superior do chafariz e posterior repartição pelas dependências necessitadas desse recurso natural.

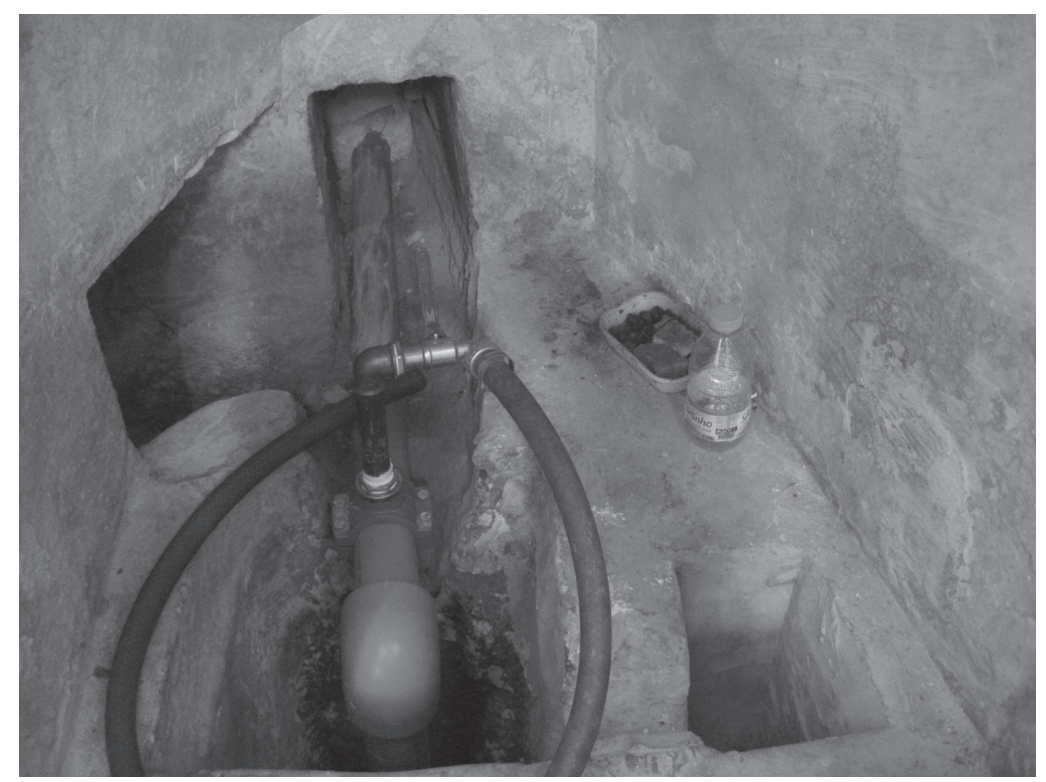

Fig. 20 - Alcobaça. Abadia Cisterciense. Tanque de compensação, embebido na parede meridional da igreja. Fotog. Virgolino Jorge

Portugal)", em Léon Pressouyre e Paul Benoit (eds.), L'hydraulique monastique. Milieux, réseaux, usages, cit., p. 235-245, e Manuela Justino Tomé, Maria Filomena Monteiro, Maria da Graça Cornacho e Virgolino Ferreira Jorge, “Aspectos da Hidráulica do Mosteiro Cisterciense de São Dinis de Odivelas", em José Manuel Mascarenhas, Maria Helena Abecasis e Virgolino Ferreira Jorge (eds.), Hidráulica Monástica Medieval e Moderna, cit., p. 241-254.

29 A sua implantação elevada sobre a própria conduta é um precioso auxiliar na identificação visual dos trajectos subterrâneos de antigos aquedutos, nomeadamente em meio rural. Deste modo, e sem dificuldades, reconhecemos e definimos o traçado adutor de abastecimento de água potável aos mosteiros de Alcobaça e de Lafões, nos seus itinerários mais escondidos. 
No estado actual de desactivação das antigas estruturas de transporte da água potável aos nossos mosteiros cistercienses, é difícil estimar com exactidão a medida do débito efectivo daqueles aquedutos, quando ignoramos algumas das suas características ou parâmetros principais. A eficiência hidráulica dependia de vários factores, nomeadamente: secção, diâmetro e rugosidade material da caleira ${ }^{30}$, perímetro molhado, declives e comprimento da canalização. Do cálculo destes valores, resultava a capacidade potencial da rede adutora (por exemplo, de 15 1/s ou $\left.1300 \mathrm{~m}^{3} / \mathrm{dia}\right)^{31}$.

\section{Distribuição de Água Potável}

A rede de alimentação interna da água fresca está construída, basicamente, segundo um esquema afirmado e desenvolvido, a partir do lavatório ou da fonte do claustro, que constituem a estrutura central de divisão e controlo hídricos através dos edifícios conventuais ${ }^{32}$.

A casa do lavatório (domus lavatoria) é uma pequena construção, em geral de planta quadrada, com um chafariz de água corrente ${ }^{33}$. O lavatório acomoda-se ao vão de uma arcada da galeria do claustro defronte ao portal do refeitório, com acesso aberto para as abluções regulares ou suplementares dos monges ${ }^{34}$. No estado actual das nossas abadias cistercienses, somente Alcobaça tem a casa do lavatório, mas numa versão primitiva do chafariz e da cobertura alterados com as obras do sobreclaustro (Figs. 21-22) ${ }^{35}$. Noutras casas da Ordem, mercê das

${ }^{30}$ O corte transversal das caleiras variava, na forma e na dimensão, sendo a geometria das aberturas semicircular e trapezoidal a mais comum (secção em U ou em V abertos).

31 Segundo a fórmula de Manning-Strickler. Acerca das regras de cálculo mais usadas para determinar o escoamento da água, vejam-se António de Carvalho Quintela, Hidráulica, Lisboa, Fundação Calouste Gulbenkian, 1985, p. 151-159, ou A. Trevor Hodge, Roman Aqueducts \& Water Supply, Londres, Duckworth, 2002, p. 349-355. A título de informação, refira-se que a pendente média do aqueduto de Alcobaça é de $1,6 \%$ ( $\angle \mathrm{h}=1,6 \mathrm{~m} / \mathrm{km})$.

32 Os lavatórios e as fontes medievais devem ser lidos e apreciados, em simultâneo, como uma obra da arte e da técnica de antanho. Pela sua funcionalidade, perfeição, equilíbrio formal e simplicidade decorativa, tão ao gosto do espírito cisterciense primitivo, eles enriquecem a beleza do claustro, como o "coração" do mosteiro.

33 A sua posição central e com algumas bicas facilitava a circulação e o uso fácil e simultâneo por vários monges.

${ }^{34}$ Para a lavagem da roupa e das vestes litúrgicas, os monges utilizavam a corrente do ribeiro ou da levada, em sítio apropriado, e não o lavatório ou a fonte do claustro, a fim de não inquinar a sua água.

35 Nas abadias medievais, habitualmente, os claustros são térreos. A construção das galerias superiores do claustro dionisíaco de Alcobaça (o chamado "claustro do silêncio") é tardia e data do século XVI. 


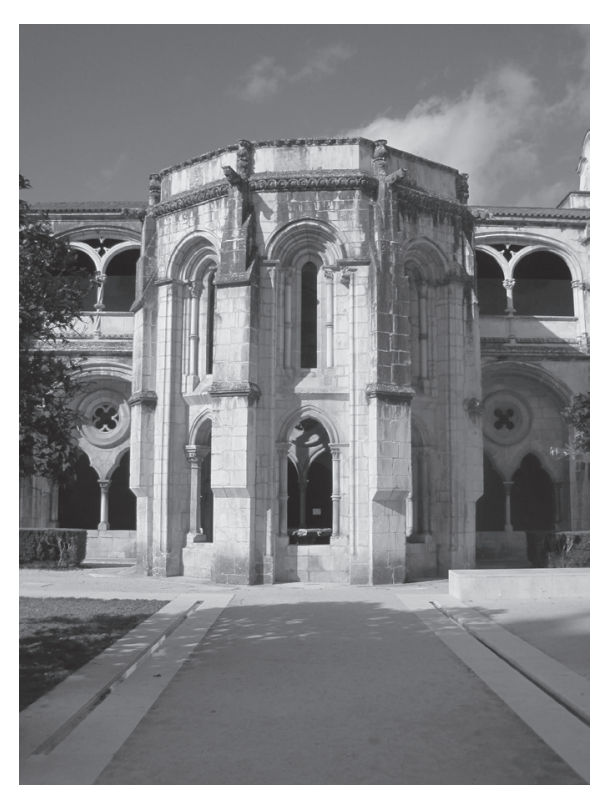

Fig. 21 - Alcobaça. Abadia Cisterciense.

Exterior da casa do lavatório.

Fotog. Virgolino Jorge

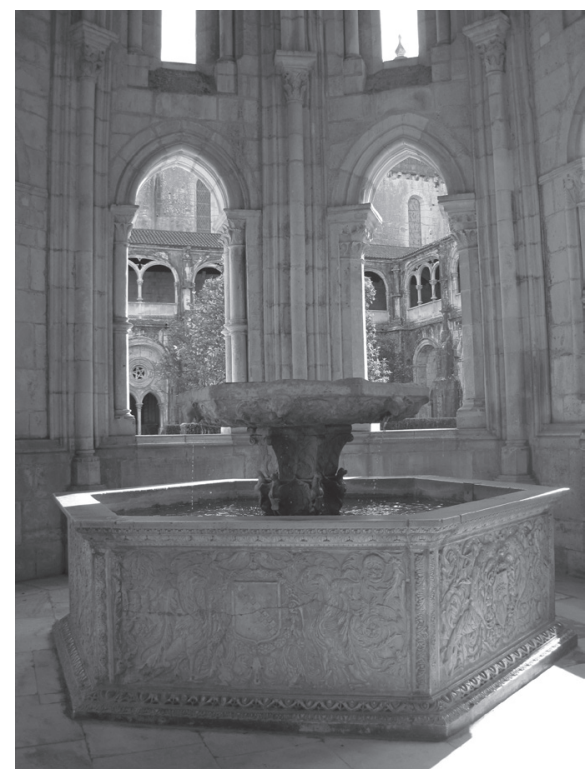

Fig. 22 - Alcobaça. Abadia Cisterciense. Interior da casa do lavatório.

Fotog. Virgolino Jorge

vicissitudes dos tempos posteriores à sua secularização, ignora-se a existência arquitectónica e arqueologicamente comprovada desta estrutura funcional (em Salzedas ou Tarouca, por exemplo ${ }^{36}$ ).

A disponibilidade de água potável, nos restantes mosteiros, efectuava-se no chafariz do claustro (Fig. 23) ou por intermédio de reservatórios e pias de adução manual, incorporados numa parede adjacente ao refeitório (caso de Lafões, certamente devido à pequenez do seu agregado comunitário).

Tanto nos lavatórios como nas fontes, a água do aqueduto chegava sob pressão e afluía pelo interior de um dos colunelos até à bica da taça superior do chafariz. Depois, a água fresca descia através de outro colunelo e era repartida pelos espaços mais carenciados desse aprovisionamento (sobretudo cozinha,

36 Por documento de visitação ao Mosteiro de Tarouca, datado de Abril de 1536, sabemos que a "aguoa vinha jumto da porta do refeitorjo domde ajmda aguora esta huã pya ou lauatorio pera todo o seruiço do dictõ mosteiro". Relativamente ao Mosteiro de Salzedas, um excerto da visitação efectuada naquele mês e ano refere a urgência de concluir a "obra que them começada de trazer agoa da fomte pera o lauatorio da porta do refeitorio que amtigamente soya a vir". Cf. Saul António Gomes, Visitações a Mosteiros Cistercienses em Portugal. Séculos XV e XVI, cit., p. 318 e 326. 


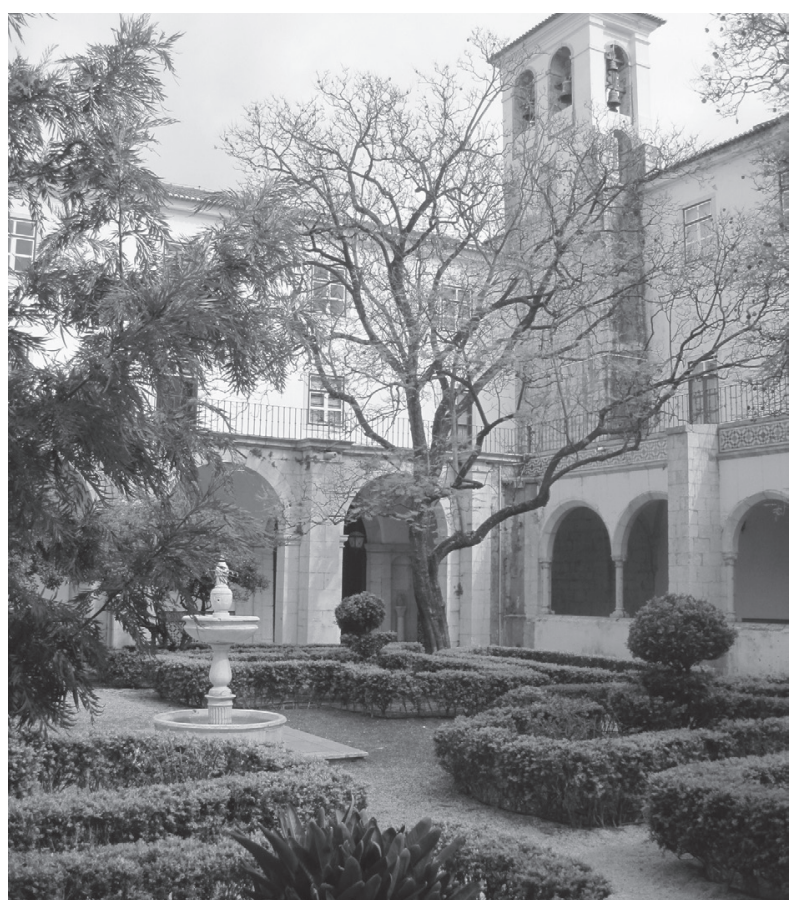

Fig. 23 - Odivelas. Mosteiro Cisterciense. Chafariz do claustro. Fotog. Virgolino Jorge

zona dos conversos e enfermaria). Os excedentes de água caíam na taça inferior ou no tanque e escoavam-se, através de descarregadores de superfície, para o colector das retretes.

As canalizações e as tubagens utilizadas nos circuitos internos da água potável têm os calibres e os materiais adequados ao regime e ao caudal de transporte. Devido à sua disponibilidade local, custos de manufactura e duração, as condutas distribuidoras eram normalmente feitas de pedra ou de barro cozido. Menos comuns, são os tubos de chumbo, porventura devido ao seu custo e à sua toxicidade ${ }^{37}$.

37 Os textos de Vitrúvio ( 24 d. C.) já referem que a tubagem cerâmica oferece uma execução mais fácil e barata do que a de chumbo, além de ser também mais saudável para a água transportada. Cf. Vitrúvio, Tratado de Arquitectura (tradução, introdução e notas por M. Justino Maciel), livro VIII, capítulo VI, nº 10, Lisboa, IST Press, 2009, p. 315. 
Para assinalar os caminhos subterrâneos da água fresca, que atravessam os edifícios monásticos, e com vista a facilitar os trabalhos da sua manutenção ou reparação futuros, há indicadores ou letreiros nas paredes sobrepostas com a epígrafe característica, em vernáculo ou em latim, "cano", "aqua" ou "aquae ductus" (cite-se e sublinhe-se a conhecida rubrica AQUE DUCTVS gravada no alçado interior norte da igreja de Alcobaça - Fig. 24) ${ }^{38}$.

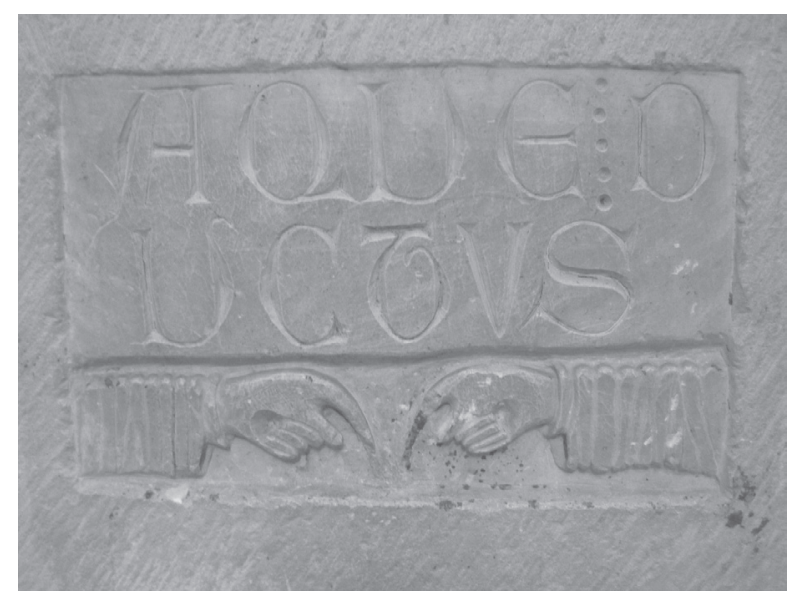

Fig. 24 - Alcobaça. Abadia Cisterciense. Lápide "AQUE DUCTVS", no alçado interior norte da igreja. Fotog. Virgolino Jorge

\section{Captação, Transporte e Distribuição de Água Comum}

Devido à diferença de nível entre as instalações monásticas e o rio ou ribeiro próximos, foi frequente a necessidade de construir um açude, a montante dessa corrente e em cota superior adequada à do cenóbio, a fim de represar a água e elevar o volume e a altura do seu caudal. Uma parte desse fluxo era desviada e conduzida directamente e ao ar livre para o mosteiro, através de uma levada aberta para o efeito. Em função de circunstâncias específicas ou extraordinárias, o controlo do débito ou a interrupção hídrica no canal eram efectuados por meio de uma comporta ou "monge", localizada na captação (Fig. 25)

${ }^{38}$ A propósito desta inscrição em latim arcaico, que encima a travessia da conduta de água potável pelo templo, veja-se o interessante estudo de Clark Maines, "Word and Image - Meaning and Function: The Aquae Ductus Relief at Santa Maria de Alcobaça", Cîteaux, 57 (2006), p. 5-44.

39 Devido à fama monástica obtida com a construção de comportas, estes dispositivos são regionalmente nomeados também pelo vocábulo "monge". 


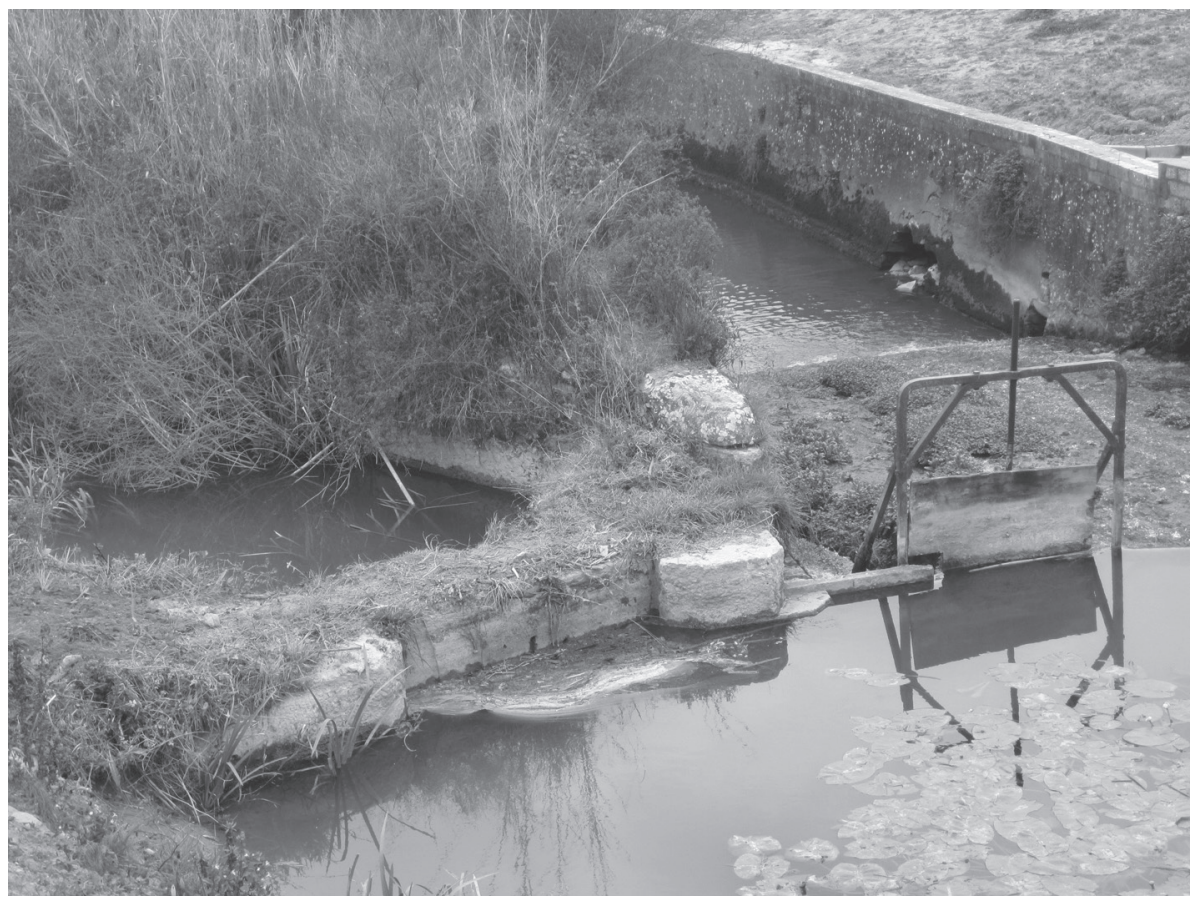

Fig. 25 - Alcobaça. Abadia Cisterciense. Açude para captação de água comum, no rio Alcoa. Fotog. Virgolino Jorge

Sempre que as características topomorfológicas das áreas atravessadas pela "água levada" o impuseram, mercê de alterações pontuais ao declive natural exigido para a adução gravítica, houve que "corrigir" a rota da conduta, com uma inflexão curvilínea favorável à perda ou à aceleração da velocidade de deslizamento (como mostra e esclarece o meandro ou "joelho" da vala de Alcobaça, no segmento entre o referido dique e o Bairro do Lameirão, antes de correr paralela ao aqueduto, formando este uma mota - Fig. 26) ${ }^{40}$.

A quantidade de água fluvial a prover ao complexo monástico era mais importante do que a sua potabilidade, atendendo aos fins industriais e domésticos a que se destinava. A levada constituía o corredor líquido primário, que garantia o funcionamento hidráulico dos moinhos e forjas, a manutenção de viveiros piscícolas, a descarga das águas usadas e de precipitação e a limpeza

40 Uma levada necessita de mais inclinação do que uma conduta de água potável, pois aquela corrente, a céu aberto, está sujeita a um atrito maior, devido à resistência e à erosão do leito e das margens. 


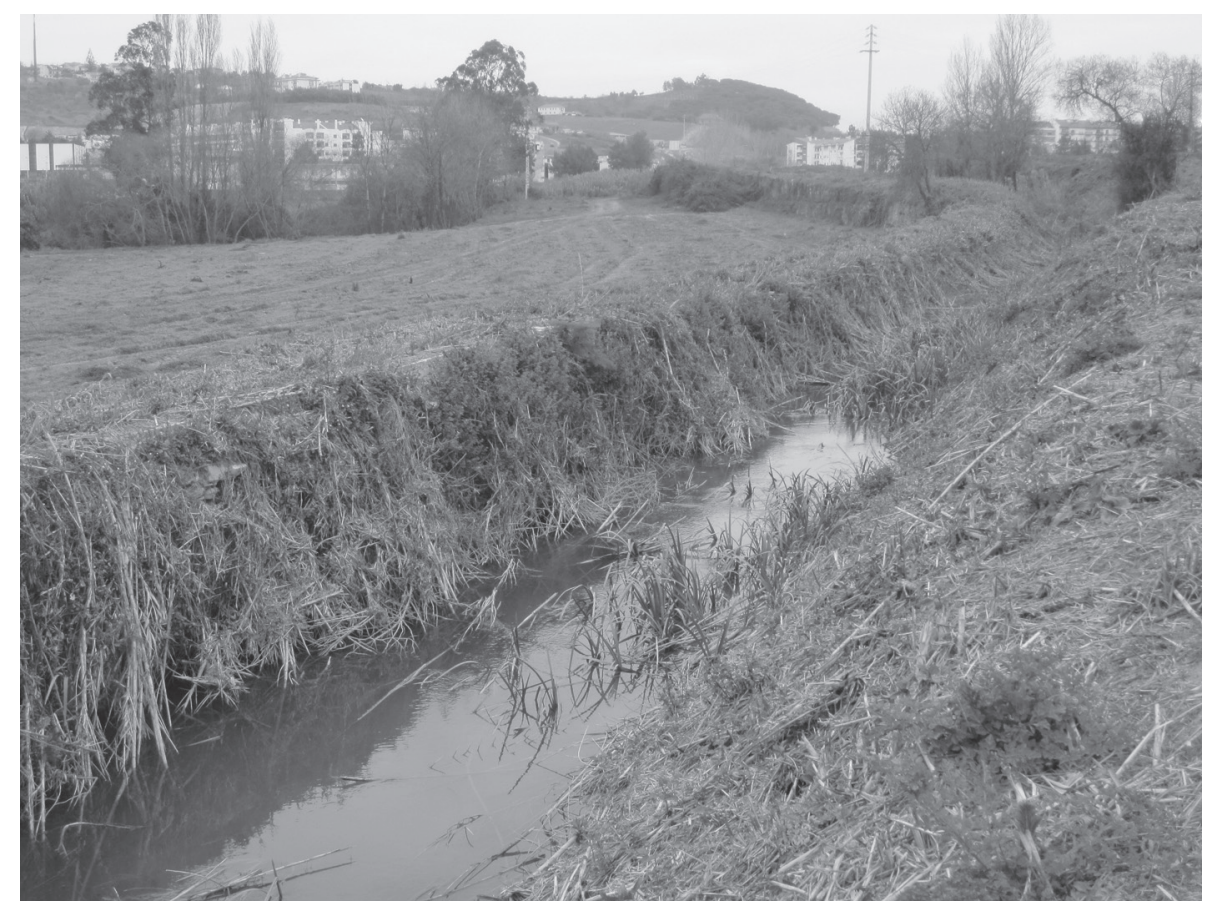

Fig. 26 - Alcobaça. Abadia Cisterciense. Meandro da levada, antes do Bairro do Lameirão. Fotog. Virgolino Jorge

das "privadas". Portanto, o seu caudal tinha de estar assegurado, de modo permanente e suficiente.

\section{Evacuação das Águas Usadas}

As águas comuns e servidas, procedentes dos múltiplos desempenhos domésticos e industriais, bem como o remanescente do lavatório ou da fonte e os esgotos pluviais do claustro, eram aproveitados e afluíam para colectores secundários que os lançavam no canal-mor de evacuação, reforçando o seu volume. Esta levada, que percorria a extremidade das alas dos monges e dos conversos e passava sob os blocos das respectivas latrinas (necessária) e refeitórios, garantia o saneamento contínuo dos dejectos e a evacuação final dos efluentes gerais, expulsando-os para além da cerca monástica, a jusante da vala ou do citado arroio (Figs. 27-28).

Com essa última diligência higiossanitária, concluía-se o ciclo hidráulico ou programa de execução infra-estrutural do esmerado sistema binário de 


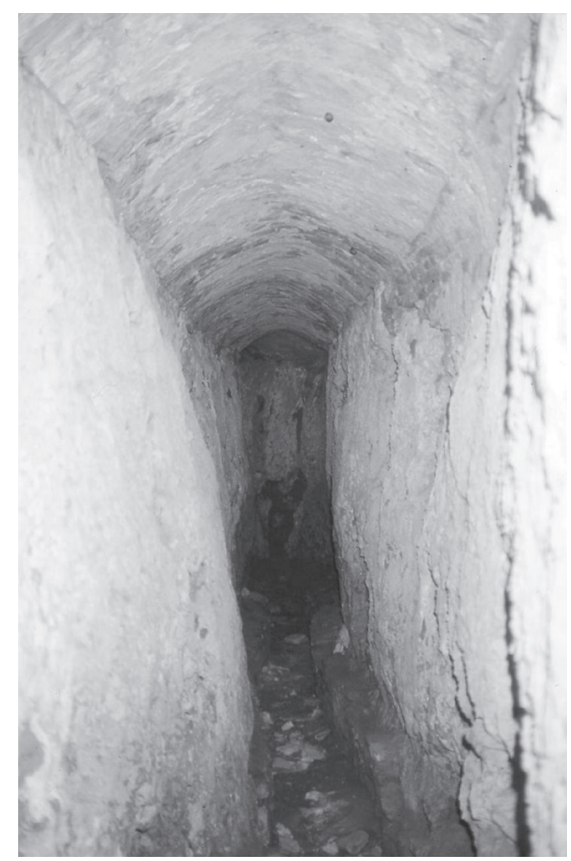

Fig. 27 - Almoster. Abadia Cisterciense. Conduta de evacuação de águas usadas. Fotog. Virgolino Jorge

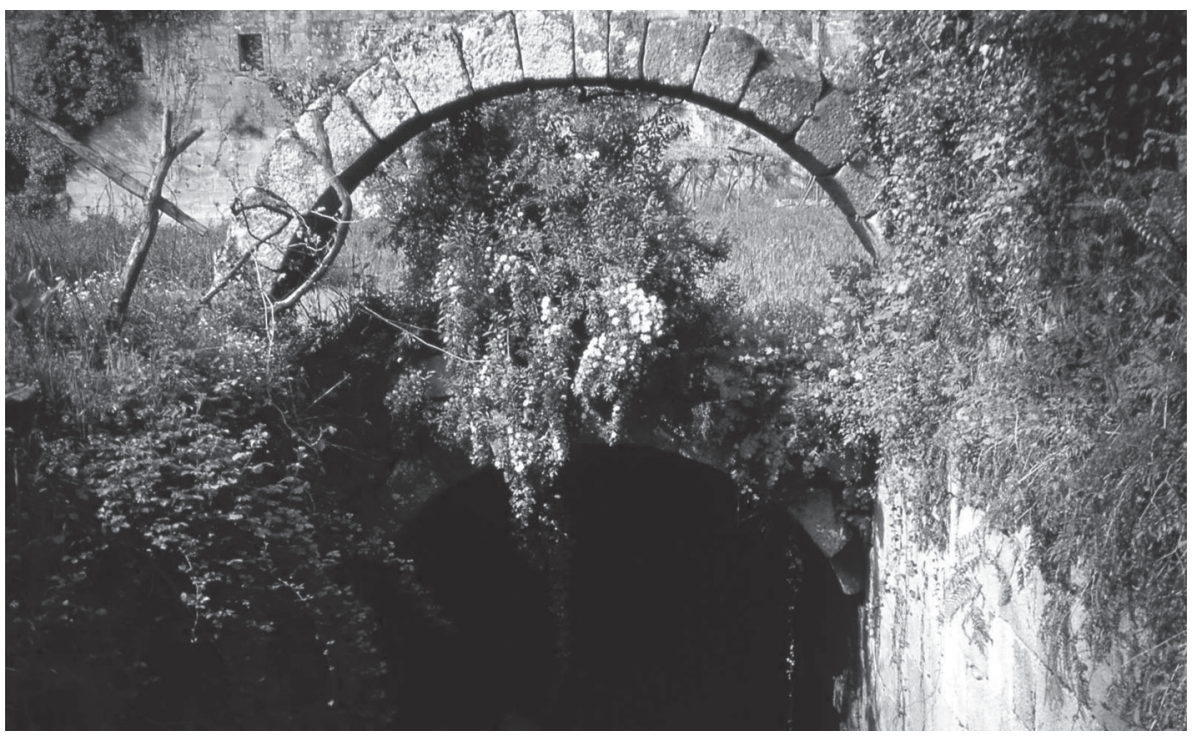

Fig. 28 - Tarouca. Abadia Cisterciense. Antigo canal das latrinas. Fotog.Virgolino Jorge 
abastecimento de águas e da rede de esgotos típico de uma abadia cisterciense da Idade Média.

\section{Epílogo: Existe uma Hidráulica Cisterciense?}

Os primeiros monges brancos legaram-nos uma verdadeira summa do seu saber e habilidade em matéria hidráulica, amplamente comprovada com a exploração de mananciais, construção de diques, albufeiras, aquedutos, moinhos, canais de rega e reservatórios, meandrizações, transferência de cursos fluviais, abertura de valados e de poços de ressumação, operações de nivelamento, cálculo de pendentes, traçado de condutas, etc. É conhecida e exaltada a sua tradicional perícia no manejo da hidrotecnologia e da engenharia sanitária em meio rural, sem dúvida cultivada nos princípios comuns da distendida "modernidade" romana equivalente e denotando conhecimentos adquiridos em antigas abadias beneditinas. A melhoria e a adaptação dessas capacidades assimiladas às exigências específicas dos numerosos mosteiros e da vida interna das suas congregações não traduzem um mimetismo tecnológico vulgar nem subtraem valor imanente ou força gerativa ao conjunto daqueles cometimentos históricos.

Em termos de concepção e obra, as elaboradas redes hidráulicas das abadias medievais de Cister reflectem o nível mais avançado de experimentos e requisitos higienizantes daquela época, o qual isentou as suas comunidades do tropel de doenças epidémicas e de mortes frequentes que tinham origem hídrica e assolavam o país coetâneo. Sem esforço, adivinhamos a insuficiência das condições de limpeza e de salubridade do escasso aprovisionamento de água e do processo de saneamento residual feitos aos palácios mais importantes e às populações citadinas de então $0^{41}$.

Como referimos já, o indiscutível protagonismo dos Cistercienses, como ardentes promotores e exploradores dos usos e das potencialidades da água, consistiu menos em inventar e mais em melhorar e fomentar o inventado, com uma visão fecunda e uma compreensão pragmática dos saberes hidrotécnicos importados. Manifestaram-no, à saciedade, em género e número, através das estruturas e trabalhos afins empreendidos nas suas abadias mais antigas, alguns de grande dificuldade operativa, face aos limites de uma época dominada pelo empirismo, para ultrapassarem os obstáculos naturais e construírem o seu território habitacional. De facto, não existe uma tecnologia hidráulica de

${ }^{41}$ A título de exemplo, cite-se Maria Filomena Mourato Monteiro e Virgolino Ferreira Jorge, "O sistema hidráulico quinhentista da cidade de Évora", Monumentos, 26 (2007), p. 92-99. 
matriz cisterciense absoluta, mas uma hidráulica incrementada, aperfeiçoada e difundida por esta grande e enérgica família religiosa, com ajustamentos práticos e maturidade consolidada. Os resultados substanciais espelham a vocação e o olhar diligente e dinâmico dos monges operários, durante a plenitude da sua Ordem, acrescentando-lhe uma nova dimensão e um significado mais concreto. O alcance e a importância capital deste património de engenho notável - desta febre hidráulica cisterciense - documentam aspectos evolucionados ou inéditos, nas suas convergências e diferenças funcionais, sobretudo no domínio da força hidráulica como motriz aplicada à actividade industrial ${ }^{42}$. Para além deste feito maior, quase monopolizado e que não se esgota em si, ganham também eco e nexo admiráveis várias obras de construção, modelação, manutenção e garantia de pureza bacteriológica da água para o consumo doméstico e os eficazes sistemas integrados de evacuação final dos esgotos, que completam e legitimam tal mestria, actualização e importância emergentes para aquele recuado tempo.

Pelo valor histórico e sentido hidráulico qualificados e implícitos, o conteúdo e a riqueza dessas acções e razões objectivas corroboram e autorizam, quiçá sem exagero de asserção, o argumento favorável a uma intuída e firmada "escolaridade" cisterciense de arquitectura hidráulica.

\section{Considerações e Perspectivas}

O levantamento topográfico, arquitectónico e de registo visual, rigoroso e explícito, da rede hidráulica de um mosteiro antigo é um afã dispendioso, pelos meios técnicos e humanos implicados. De maneira geral, os circuitos da água são subterrâneos, principalmente no recinto monástico; logo, ordenam a realização prévia de trabalhos de prospecção arqueológica extensos, para o seu exame físico e análise pormenorizados. Estas tarefas continuam a faltar-nos, em parâmetros satisfatórios, e a impedir ou limitar a legibilidade garantida e reconstituída dos hidrossistemas, de montante a jusante, e a dificultar a sua cronologia faseada e exacta. Daí que, em muitos complexos abaciais, a nossa avaliação hidráulica fique irremediavelmente circunscrita a hipóteses e ideias vagas ou especulativas, acerca do seu modo e concepção funcional. Permanecem por identificar e esclarecer algumas questões obscuras ou lacunares, relativas ao itinerário das condutas, que constituem um estímulo e um convite para o

42 Sobre forjas hidráulicas cistercienses medievais, embora confinado ao caso francês, veja-se Paul Benoit e Karine Berthier, 'L'innovation dans l'exploitation de l'énergie hydraulique d'après le cas des monastères cisterciens de Bourgogne, Champagne et Franche-Comté", em P. Beck (dir.), L'innovation technique au Moyen Âge, Paris, Errance, 1998, p. 58-66. 
prosseguimento e debate das nossas pesquisas. A maioria dessas estruturas ainda se conserva in situ, ocultas ou superficiais, no termo dos antigos cenóbios, mas em estado de abandono, desgaste ou desmembramento generalizados.

Perante as dificuldades e restrições supracitadas, compreende-se a imerecida incipiência da investigação arqueológica portuguesa, quanto ao audacioso labor construtivo hidráulico cisterciense, a reclamar mais apreço futuro e dignificação patrimonial. Por conseguinte, a averiguação do impulso e da competência historicamente atribuídos ao esforço mobilizador e ao génio politécnico dos discípulos de São Bernardo de Claraval (1090-1153), para as práticas de economia e gestão dos recursos hídricos, é um tema especial que ainda está nos seus inícios, entre nós. Logo, constitui um campo aberto de estudo e discussão privilegiados, a "escavar" e redescobrir por arqueólogos, historiadores, arquitectos e engenheiros, entre outros especialistas, a fim de escrutarem e discernirem, à distância temporal, a justeza do tributo da Ordem de Cister para a história das técnicas, fragmentariamente explorado neste ambicioso intróito ao tema. O desafio interdisciplinar, de colaboração tão estimulante como incontestável, poderá repercutir-se no procedimento das escalas de análise cruzada e no resultado aprofundado dessas pesquisas. Ademais, permite validar ou corrigir e ampliar o horizonte destas notas genéricas e sucintas, essencialmente descritas e suportadas pelo conhecimento e experiência pessoais acumulados e desenvolvidos ao longo de duas décadas de animado trabalho de campo e de reflexão, com incidência particular na "hidromania" cisterciense. 